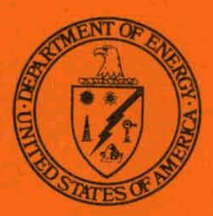

A Technology

Assessment of

Solar Energy Systems

\title{
Environmental Residuals and Capital Cost of Energy Recovery From Municipal Sludge and Feedlot Manure
}

\section{MASTER}

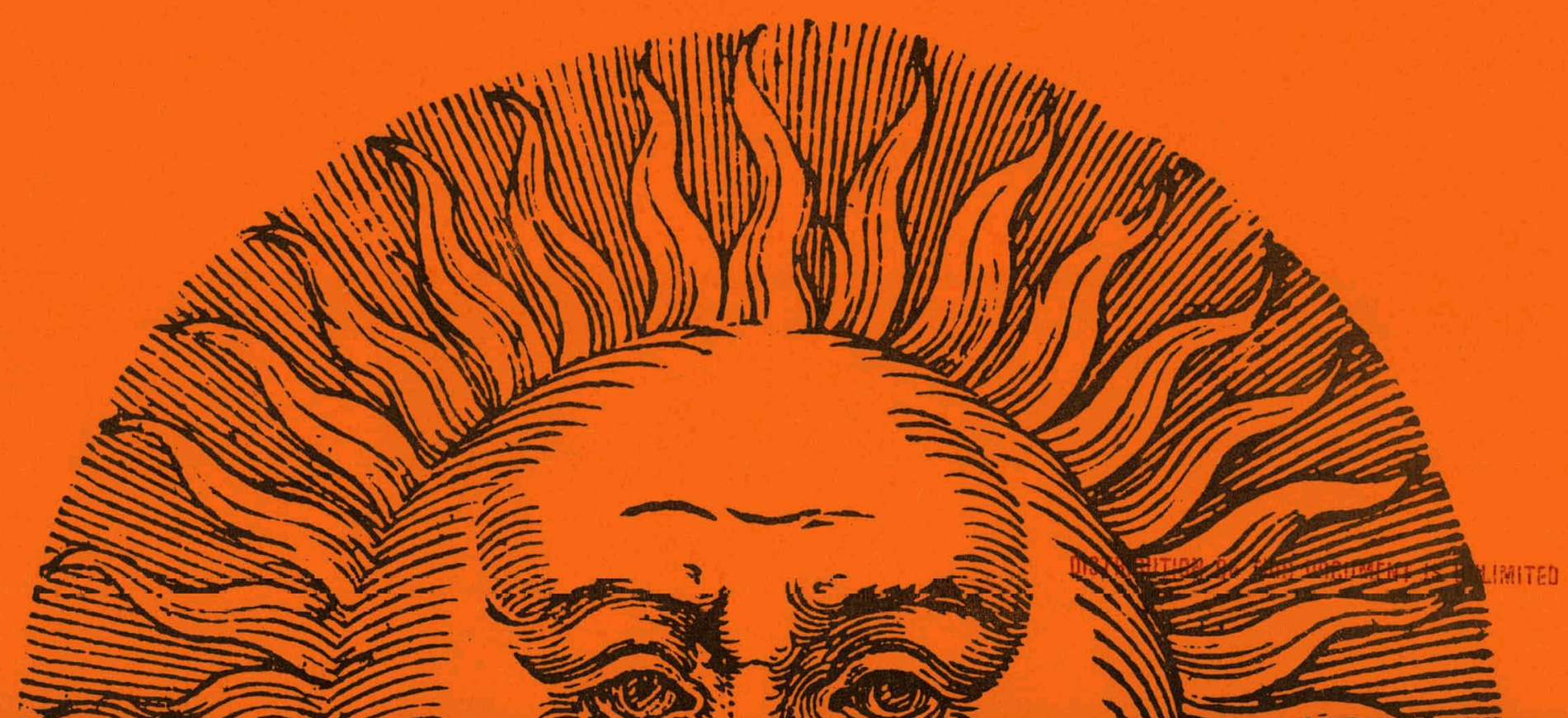




\section{DISCLAIMER}

This report was prepared as an account of work sponsored by an agency of the United States Government. Neither the United States Government nor any agency Thereof, nor any of their employees, makes any warranty, express or implied, or assumes any legal liability or responsibility for the accuracy, completeness, or usefulness of any information, apparatus, product, or process disclosed, or represents that its use would not infringe privately owned rights. Reference herein to any specific commercial product, process, or service by trade name, trademark, manufacturer, or otherwise does not necessarily constitute or imply its endorsement, recommendation, or favoring by the United States Government or any agency thereof. The views and opinions of authors expressed herein do not necessarily state or reflect those of the United States Government or any agency thereof. 


\section{DISCLAIMER}

Portions of this document may be illegible in electronic image products. Images are produced from the best available original document. 
Printed in the United States of America Available from

National Technical Information Service U.S. Department of Commerce

5285 Port Royal Road

Springfield, VA 22161

NTIS price codes

Printed Copy: $\quad \$ 6.00$

Microfiche Copy: $\$ 3.50$ 
Prepared by:

Argonne National Laboratory

\section{U.S. Department of Energy Assistant Secretary for Environment Office of Environmental Assessments Washington, D.C. 20545}

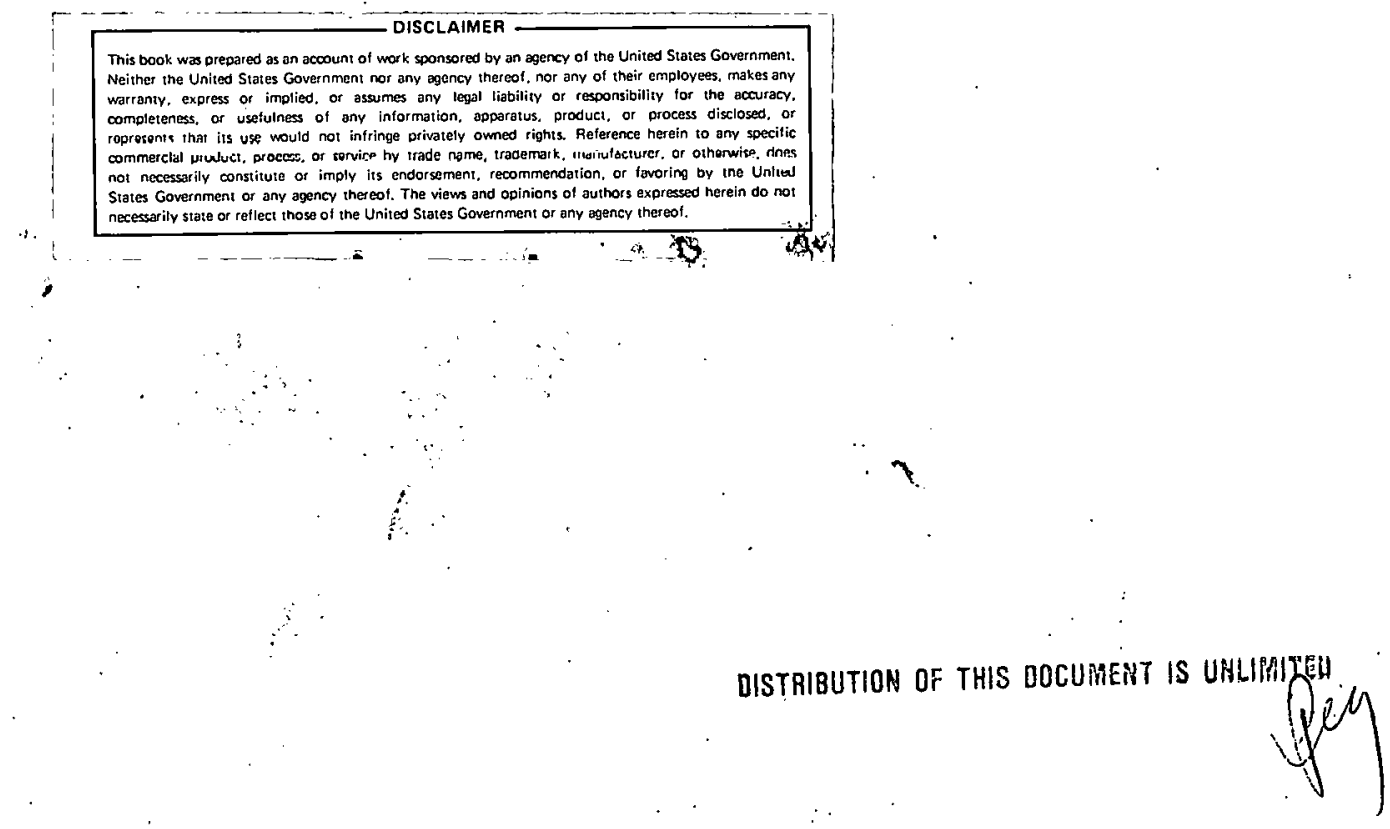


The U. S. Department of Energy, Office of Environment, Office of Environmental Assessments, is conducting a project entitled Technology Assessment of Solar Energy (TASE) Systems, to evaluate the range of potential environmental, health, and socioeconomic consequences of rapid, large-scale commercialization of solar technologies. The goal of this project is to identify and analyze both the positive and negative effects of solar technology deployment. The project will provide a basis for avoiding potential problems and for grasping opportunities during the transition to solar energy in the $U$. S.

Massive solar development will force major increases in the use of those raw materials needed to make solar system components. Along with this increased resource consumption and production will come associated pollution. In addition, rapid solar energy development may mean significant secondary or unplanned changes in institutions and lifestyles as the nation moves toward greater use of solar energy systems. The TASE project is designed to provide a quantitative analysis of the direct and indirect effects of solar energy use. In so doing, it will help define an environmentally acceptable solar future.

This report is an element of the TASE Solar Technology Characterization Series. We would like to express our appreciation to Terry Surles of the Argonne National Laboratory for his efforts in preparing this document.

Dr. Gregory J. D'Alessio

TASE Project Director

Technology Assessments Division

Dr. Robert $P$. Blaunstein, Manager

Conservation, Solar, and Geothermal Programs

Technology Assessments Division 
1 INTRODUCTION . . . . . . . . . . . . . . . . . . . . . . 1

1.1 Methodology . . . . . . . . . . . . . . . . . . 2

1.2 Feedstock Characteristics . . . . . . . . . . . . . . . 3

1.2.1 Municipal Sludge . . . . . . . . . . . . . . . 3

1.2 .2 Manure... . . . . . . . . . . . . . . . . 3

1.3 Technologies Selected for Study . . . . . . . . . . . . . . 4

1.3.1 Anaerobic Digestion ................. 4

1.3 .2 Incineration . . . . . . . . . . . . . . . . 5

1.3.3 Pyrolysis . . . . . . . . . . . . . . . . . 6

2 SLUDGE-CONVERSION SYSTEMS: PROCESS CHARACTERISTICS, ENVIRONMENTAL

DATA, AND CAPITAL COSTS . . . . . . . . . . . . . . . . . . . . 7

2.1 Anaerobic Digestion of Municipal Sludge . . . . . . . . . . . . 7

2.1.1 Process Characteristics . . . . . . . . . . . 7

2.1.2 Environmental Data . . . . . . . . . . . . . 9

2.1.3 Capital Costs .................... 11

2.2 Incineration of Municipal Sludge . . . . . . . . . . . . 11

2.2.1 Process Characteristics . . . . . . . . . . . . 13

2.2.2 Environmental Data . . . . . . . . . . . . . . . 13

2.2.3 Capital Costs .................. 15

2.3 Pyrolysis of Municipal sludge . . . . . . . . . . . . . . 17

2.3.1 Process Characteristics . . . . . . . . . . . . 17

2.3.2 Environmental Data . . . . . . . . . . . . . . . 18

2.3.3 Capital Costs . . . . . . . . . . . . . . . . 20

3 MANURE-CONVERSION SYSTEMS: PROCESS CHARACTERISTICS, ENVIRONMENTAL

DATA, AND CAPITAL COSTS . . . . . . . . . . . . . . . . . . . . 21

3.1 Anaerobic Digestion of Feedlot Manure . . . . . . . . . . . . . 21

3.1.1 Process Characteristics . . . . . . . . . . . . 21

3.1.2 Environmental Data . . . . . . . . . . . . . . . 24

3.1.3 Capital Costs ................... 24 
3.2 Incineration of Feedlot Manure . . . . . . . . . . . . . . . 25

3.3 Pyrolysis of Feedlot Manure . . . . . . ... . . . . . . 27

3.3.1 Process Characteristics . . . . . . . . . . . . 27

3.3.2 Environmental Data................... 29

3.3.3 Capital Costs ................... 31

4 DISCUSSION . . . . . . . . . . . . . . . . . . . 32

REFERENCES . . . . . . . . . . . . . . . . . . . . . 33

BIBLIOGRAPHY . . . . . . . . . . . . . . . . . . 35 
No.

PAGE

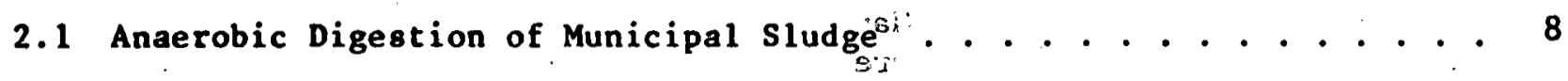

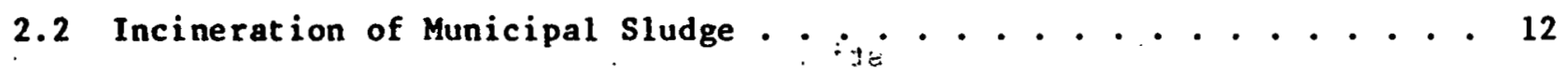

2.3 Pyrolysis of Municipal sludge . . . . . . . . . . . . . . 16

3.1 Anaerobic Digestion of Manure . . . . . . . . . . . . . . . . . . 22

3.2 Pyrolysis of Manure . . . . . . . . . . . . . . . . . . . 26 
No.

1.1 Assumed Composition of Municipal Sludge Solids . . . . . . . . . . . 3

1.2 Metal Content of Municipal Sludge . . . . . . . . . . . . . . 3

1.3 Summary of Animal Waste Characteristics . . . . . . . . . . . . 4

1.4 Composition of Semicomposted Manure . . . . . . . . . . . . . . . . 4

2.1 Energy Production Characteristics of Anaerobic Digestion of

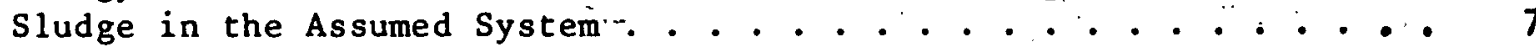

2.2 Amounts of Materials Required for the Sludge Digestion Plant Assumed ......... . . . . . . . . . . . . . .

2.3 Residuals from Anaerobic Digestion of 242 Tons/Day of Municipal Sludge Solids ......................... . . . 10

2.4 Reported Ranges and. Means of Metal. Concentrations (ppm) in Various Municipal sludges . . . . . . . . . . . . . . . . 10

2.5 Construction Costs for a 200-MGPD Anaerobic Sludge Digestion Plant . . . . . . . . . . . . . . ......... 11

2.6 Energy Production Characteristics of Sludge Incineration in the Assumed System . . . . . . . . . . . . . . . . . . 11

2.7 Amounts of Materials Required for the Sludge Incineration Plant As sumed . . . . . . . . . . . . . . . .........

2.8 Residuals from Incineration of 354 Tons/Day of Municipal Sludge Solids . . . . . . . . . . . . . . . . . . . . . . . .

2.9 Distribution of Metals in Sludge-Incineration Wastes, Per Quad of Energy Produced . . . . . . . . . . . . . . . . . . . .

2.10 Construction Costs for a 300-MGPD Sludge Incineration Plant ....

2.11 Energy Production Characteristics of Sludge Pyrolysis in the Assumed System . . . . . . . . . . . . . . . . . . . . .

2.12 Amounts of Materials Required for the Sludge Pyrolysis Plant As sumed

2.13 Residuals from Pyrolysis of Sludge from a 300-MGD Treatment Plant..

2.14 Distribution of Metals in Sludge-Pyrolysis Wastes, Per Quad of Energy Produced 


\section{LIST OF TABLES (CONT'D)}

No.

2.15 Construction Costs for a 300-MGPD Sludge Pyrolysis Plant . . . . . . 20

3.1 Energy Production Characteristics of Anaerobic Digestion of

Manure in the Assumed System . . . . . . . . . . . . . . . 23

3.2 Amounts of Materials Required for the Manure Digestion Plant

Assumed . . . . . . . . . . . . . . . . . . . . . 23

3.3 Residuals from Anaerobic Digestion of Mânure from 25,000 Cattle... 24

3.4 Metal Content of Manure in Various Stagês of Digestion . . . . . . . 25

3.5 Construction Costs of an Anaerobic Manure Digestion Plant . . . . . . 25

3.6 Energy.Production Characteristics of Manure Pyrolysis in the

Assumed System . . . . . . . . . . . . . . . . . . . 27

3.7 Pyrolysis Gas Composition . . . . . . . . . . . . . . . . . 28

3.8 Amounts of Materials Required for the Manure Pyrolysis Plant Assumed ............................. . . 29

3.9 Residuals from Pyrolysis of Manure from 145,000 Cattle . . . . . 30

3.10 Distribution of Metals in Manure-Pyrolysis Wastes Per Quad of Energy Produced . . . . . . . . . . . . . . . . . . . 30

3.11 Construction Costs for a Fluidized-Bed Manure Pyrolysis Plant . . . . 31 


\title{
ENVIRONMENTAL RESIDUALS AND CAPITAL COSTS OF ENERGY RECOVERY FROM MUNICIPAL SLUDGE AND FEEDLOT MANURE
}

by

Stephen W. Ballou, Larry Dale, Ron Johnson, William Chambers, and Hank Mittelhauser

\begin{abstract}
This report analyzes the capital and environmental cost of energy recovery from municipal sludge and feedlot manure. Literature on waste processing and energy conversion and interviews with manufacturers were used for baseline data for construction of theoretical models using three energy conversion processes: anaerobic digestion, incineration, and pyrolysis. Process characteristics, environmental impact data, and capital costs are presented in detail for each conversion system. The energy recovery systems described would probably be sited near large sources of sludge and manure, i.e., metropolitan sewage treatment plants and large feedlots in cattle-raising states. Although the systems would provide benefits in terms of waste disposal as well as energy production, they would also involve additional pollution of air and water. Analysis of potential siting patterns and pollution conflicts is needed before energy recovery systems using municipal sludge can be considered as feasible energy sources.
\end{abstract}

\section{INTRODUCTION}

During the past several years, a great amount of interest has been directed toward development and eventual utilization of solar energy technologies. In addition to using a seemingly inexhaustible energy source, solar technologies are generally perceived to be relatively benign in terms of environmental, health, and safety impacts. The amount of environmental impact, however, varies with the conversion technologies, especially when construction, material supply, and environmental costs are included.

Although solar technologies are generally considered to be those that use direct solar energy (as in photovoltaics) or energy sources that are once removed from direct sunlight (such as wind or ocean thermal gradients), they also include technologies that utilize biological wastes, such as crop residues, livestock manures, and municipal sludge. The purpose of this 
study is to address the capital and environmental costs associated with energy recovery from municipal sludge and feedlot manures. Several conversion systems are evaluated to determine material requirements, capital costs, and environmental costs, the latter in terms of 1 and and water requirements and production of effluent and residual pollutants. Results of this study will be used by the Department of Energy to evaluate impacts resulting from the future deployment of solar technologies.: To that purpose, some of the findings of this study (e.g., energy production) are expressed in terms of Quads (1015 Btu) as required for incorporation into the Strategic Environmental Assessment System (SEAS), a computer program that is used to evaluate the impacts." of energy-related policies on the U.S. economy and environment.

\subsection{METHODOLOGY}

Our approach to the etudy began with collection of the necessary base data on process designs and operating parameters. The literature is not voluminous and does not contain all of the base information that we required; therefore we interviewed, over the telephone, many manufacturers and users of waste-processing and energy-conversion equipment to verify or update design parameters and operating costs. In some cases neither the literature nor our telephone informants could give us firm figures. In these cases it was necessary to assume plant designs and operating parameters on the basis of characteristics of similar equipment commonly used in other industrial processes. From these basic engineering assumptions, it was then possible to calculate the required cost and environmental details.

Several assumptions were made in evaluating pollution and cost data for the conversion systems described in this report. In the case of sludge conversion systems, we assumed that conversion facilities would be located on the same sites as existing wastewater treatment plants. Capital costs, therefore, would relate only to the additional conversion facilities. Consequently, collection and transportation costs are not assumed, since they are already included in the normal operation of treatment plants. Likewise, for feedlot manure conversion, we assumed that collection and transportation costs are already borne by the feedlot operators, who collect, transport, and sell large quantities of manure for fertilizer as part of their normal operation. 1

The description of municipal sludge conversion systems is based on the assumption that energy recovery from sludge will occur in relatively large metropolitan areas. High capital costs and large energy requirements will demand large quantities of sludge. For the manure conversion technologiès; large quantities of manure will be required. Scaling down pyrolysis systems is difficult because of the high capital costs. Anaerobic digestion of manure, however, can be scaled down to smaller, decentralized operations. 


\subsection{FEEDSTOCK CHARACTERISTICS}

\subsubsection{Municipal Sludge}

Municipal sludge is a combination of human excrement, garbage grindings, industrial plant discharges, silt and grit from storm runoff, and biologically produced solids, all mixed in highly variable proportions. sludge solids are normally defined in terms of total solids and volatile solids. The volatile solids are the organic fraction of solids, from which energy may be recovered. Volatile solids range from $60 \%$ to $80 \%$ of total solids; ${ }^{2}$ we have assumed approximately $75 \%$ of the total solids. Thus, assuming an energy content of 10,000 Btu per pound of volatile solids, the heating value of sludge is $7,500 \mathrm{Btu} / \mathrm{lb}$.

The chemical composition of the volatile solids is also highly variable; we have assumed the composition shown in Table 1.1. The heavy-metal content of sludge solids is assumed to be as shown in Table 1.2.

\section{2 .2 Manure}

Cattle manure generally consists of spilled and undigested feed, lignin and hemicellulose material from undigested roughage, and 1ignoprotein complexes produced within the animial. Manure production rates from feedlot cattle average 60 wet pounds per head per day, or 6.9 pounds of dry solids per head per day, of which $86 \%$ is organic and therefore convertible to energy. Waste production by other livestock is shown in Table 1.3.3,4 Table 1.4 shows the typical composition of semicomposted manure in a nonarid climate. 5 In general, the heating value of dry, ash-free manure is $8,750 \mathrm{Btu} / 1 \mathrm{~b}$.

Table 1.1. As sumed Composition of Muncipal Sludge Solids

\begin{tabular}{lr}
\hline Component & $\begin{array}{c}\text { Percent by } \\
\text { Weight }\end{array}$ \\
\hline Carbon & 37.6 \\
Hydrogen & 5.2 \\
Oxygen & 27.0 \\
Nitrogen & 4.5 \\
Sulfur & 0.7 \\
Nonvolatile & \\
$\quad$ Solids & 25.0 \\
Total & 100.0 \\
Heating value & \\
$\quad($ Btu/1b)a & 7,500 \\
\hline
\end{tabular}

assuming $10,000 \mathrm{Btu} / 1 \mathrm{~b}$ for volatile solids.
Table 1.2. Metal Content of Municipal Sludge

\begin{tabular}{|c|c|c|c|}
\hline \multirow[b]{2}{*}{ Metal } & \multicolumn{2}{|c|}{ In Dry Solids } & \multirow{2}{*}{$\begin{array}{c}\text { 1bs/100 lbs } \\
\text { Volatile } \\
\text { Solids }\end{array}$} \\
\hline & ppm & $1 \mathrm{bs} / \mathrm{t}$ on & \\
\hline $\begin{array}{l}\text { Arsenic } \\
\text { Beryllium }\end{array}$ & $\begin{array}{l}43 \\
-a\end{array}$ & $\begin{array}{r}0.086 \\
-a\end{array}$ & $\begin{array}{r}0.0057 \\
-a\end{array}$ \\
\hline Cadmi um & 25 & 0.05 & 0.0033 \\
\hline Chromium & 1,000 & 2.0 & 0.133 \\
\hline Copper & 1,000 & 2.0 & 0.133 \\
\hline Lead & 1,000 & 2.0 & 0.133 \\
\hline Mercury & 10 & 0.02 & 0.00133 \\
\hline Nickel & 200 & 0.4 & 0.0265 \\
\hline Selenium. & 26 & 0.05 & 0.0034 \\
\hline Silver & 225 & 0.45 & 0.03 \\
\hline Zinc & 2,500 & 5.0 & 0.331 \\
\hline
\end{tabular}

anot detected.

Source: Ref. 2 . 
Table 1.3. Summary of Animal Waste Characteristicsa

\begin{tabular}{lccccccc}
\hline $\begin{array}{c}\text { Waste } \\
\text { Component }\end{array}$ & $\begin{array}{c}\text { Dairy } \\
\text { Cow }\end{array}$ & $\begin{array}{c}\text { Beef } \\
\text { Feeder }\end{array}$ & $\begin{array}{c}\text { Swine } \\
\text { Feeder }\end{array}$ & $\begin{array}{c}\text { Sheep } \\
\text { Feeder }\end{array}$ & Horse & Layer & Broiler \\
\hline Raw Manureb & 82 & 60 & 65 & 40 & 45 & 53 & 71 \\
Total Solids & 10.4 & 6.9 & 6.0 & 10.0 & 9.4 & 13.4 & 17.1 \\
Volatile Solids & 8.6 & 5.9 & 4.8 & 8.5 & 7.5 & 9.4 & 12.0 \\
Biochemical Oxygen Demand & 1.7 & 1.6 & 2.0 & 0.9 & - & 3.5 & - \\
Chemical Oxygen Demand & 9.1 & 6.6 & 5.7 & 11.8 & - & 12.0 & - \\
Nitrogen (total, as N) & 0.41 & 0.34 & 0.45 & 0.45 & 0.27 & 0.72 & 1.16 \\
Phosphorous (as P) & 0.073 & 0.11 & 0.15 & 0.066 & 0.046 & 0.28 & 0.26 \\
Pot assium (as K) & 0.27 & 0.24 & 0.30 & 0.32 & 0.17 & 0.31 & 0.36 \\
\hline
\end{tabular}

apounds of component per day per 1000 live pounds of animal.

$b_{\text {Feces }}$ and urine with no litter or bedding.

Source: Refs. 3,4.

\subsection{APPLICATIONS SELECTED FOR STUDY}

Three processes for energy recovery from municipal sludges and manures were evaluated in this study: anaerobic digestion, incineration, and pyrolysis. The rationale for selection of these processes is discussed below. In general, these technologies have a long history of application in the United states, and their operating behaviors are well understood. They will likely continue to be the primary technologies for sludge and manure conversion through 1990.

\subsubsection{Anaerobic Digestion}

Table 1.4. Composition of Semicomposted Manure

\begin{tabular}{lrc}
\hline Component & $\begin{array}{c}\text { Weight } \%, \\
\text { Wet }\end{array}$ & $\begin{array}{c}\text { Weight } \% \\
\text { Dry, ash-free }\end{array}$ \\
\hline Carbon & 18.9 & 52.2 \\
Hydrogen & 2.3 & 6.4 \\
Oxygen & 13.3 & 36.9 \\
Nitrogen & 1.2 & 3.3 \\
Sulfur & 0.4 & 1.2 \\
Ash & 13.9 & - \\
Water & 50.0 & - \\
Total & 100.0 & 100.0 \\
Heating Value & & 8,750 \\
$\quad$ (Btu/lb)a & - & \\
\hline
\end{tabular}

${ }^{a}$ Calculated from Dulong's formula.

Municipal sludge. Anaerobic digestion of municipal sludge can be used to recover energy from sludge while simultaneously destroying pathogenic organisms and odors associated with the sludge. Interest in this process has recently revived because of the benefits of methane production, improved operability due to increased understanding of the technology, and the effect of producing a more readily disposable sludge. 6 The digested sludge is usable as a soil conditioner, but its application to cropland can be limited by its nitrate and heavy-metals content. However, recent changes in water pollution control statutes, requiring industrial plants to clean their water discharges, may increase the usefulness of digested sludge as a soil conditioner. Coupling the energy production of anaerobic digestion with the 
prospect of using municipal sludge as a soil conditioner changes the treatment of municipal sludge from a waste disposal problem to a resource recovery opportunity.

The energy product resulting from anaerobic digestion of municipal sludge is a methane-carbon dioxide mixture that can be used in any powergenerating equipment that burns a gaseous fuel. Carbon dioxide content ranges from $15 \%$ to $50 \%$ by volume; removal of the carbon dioxide and other impurities leaves methane gas suitable for pipeline feed. Unfortunately, the amount of gas producible in this way from municipal sludge is negligible in comparison to the volumes of natural gas used by municipalities. Nevertheless, digester gas could provide a large part of the power needed (and at present, purchased) by municipalities for wastewater treatment. In this work we have assumed that digester gas would be used as fuel at the wastewater treatment plant that would produce the sludge fed to the digester. Other uses are possible, but we have not analyzed them in this study.

Manure. Anaerobic digestion of animal residues has been used in India for many years. Sanghi and Day report that in 1972 there were about 2,500 digesters in rural India producing biogas from cattle dung without destroying the value of the solids as fertilizer. Essentially, only carbon is driven off in the digestion process, yielding gas with a heating value of $600 \mathrm{Btu} / \mathrm{ft}^{3}$. The nutrients in fresh dung pass through and are discharged in the digested residue, which loses only a small part of the nitrogen. 3 Digested manure is considered a good source of animal feed, in addition to its utility as fertilizer.

In the United States, extensive investigations are under way to evaluate process requirements for biogas recovery from manure from feed cattle, dairy cows, swine, and poultry and from other animal wastes.8-10 One area where anaerobic digestion is close to full-scale production is the Four Corners region of Arizona, Colorado, New Mexico, and Utah, where there are many large beef feedlots.

The process characteristics reported here are based on a model plant (described in a later section) designed to process the waste from 25,000 heef cattle.

\subsubsection{Incineration}

Recovery of energy by sludge incineration involves raising steam by cooling the hot flue gases. The steam may be used for heating, but the most attractive possibility is to use steam turbines to drive motors directly, or produce electricity for the same use, in an associated wastewater treatment plant.

Incineration is primarily a means of reducing the weight and volume of municipal sludge prior to final disposal. Use of this technology is increasing because of its sludge reduction capability as well as the opportunity it presents for recovering energy from the sludge. 
The two sludge incineration techniques most common in the United States differ in the type of furnace employed. Multiple-hearth furnaces are most widely used, but fluidized bed incinerators are also used in a significant number of the installations where incineration is practiced.

The multiple-hearth furnace is shaped like a vertical cylinder and consists of an insulated steel shell surrounding a number of solid refractory hearths, one above the other, and a central rotating shaft to which rabble arms are attached. The hearths are constructed of high-heat-duty fire brick. Air and combustion gases flow up through the furnace, and sludge moves downward. Gas, oil, coal, or solid municipal waste may be used as auxiliary fuel for start-up or supplemental fuel in the incinerator. The sludge is dried in the upper hearths, where the sludge temperature is raised to about $200^{\circ} \mathrm{F}$ and most of the moisture is, driven off. The gas temperature in this zone may be as low as $800^{\circ} \mathrm{F}$ or as high as $1,400^{\circ} \mathrm{F}$. The slinge burne in the middle hearths, where the temperature is about $2,000^{\circ} \mathrm{F}$. The bottom hearths compose the ash cooling zone, in which the incoming air cools the ash to around $400^{\circ} \mathrm{F}$ before the ash leaves the furnace. The multiple-hearth furnace typically operates with $75-100 \%$ excess air. The excess of air insures that proper turbulence and mixing occurs, that the sludge is completely burned, and that the combustion gases are cool enough to protect, the refractory lining of the hearth. The central shaft and rabble arms are cooled by air flowing through tubes in their cores.

Fluidized-bed incinerators are vertical cylindrical vessels with a grid near the bottom to support a sand bed. Dewatered sludge is injected above the grid, and air (at 20-25\% excess) is injected below the grid at 3 to 5 psig; the air flows upward, fluidizing the hot sand-and-sludge mixture. Supplemental fuel may be introduced above or below the bed. The single chamber is operated at about $1,500^{\circ} \mathrm{F}$, and drying and combustion occur simultaneously in the bed.

\section{3 .3 Pyrolysis}

Pyrolysis in the absence of oxygen reduces biomass to produce useful fuels and chemicals. Hydrocarbons are thermally decomposed into a hydrogenenriched volatile phase and a carbonaceous char. At low pyrolysis temperatures, the volatile phase is composed of heavy, unsaturated hydrocarbona that are liquid, possibly even solid, at room temperature. Higher operating temperatures cause further cracking of the volatile hydrocarbons so that light hydrocarbon gases are the principal products.

Volatile products of pyrolysis can be used as chemical feedstocks and as fuels. Economics will deteruisu which application is best for these materials. For instance, the relatively low energy content of pyrolysis gases from manure may preclude transportation over any substantial distances. This means the potential markets for pyrolysis products must be nearby, or additional processing will be required to upgrade these products to materials of higher value.

Pyrolysis is a potentially efficient method for recovering energy from sewage sludge: the products can provide a significant portion of the energy required by municipal wastewater treatment plants. For manure, energy production by pyrolysis is assumed to occur near markets for the recovered energy. 


\section{SLUDGE-CONVERSION SYSTEMS: PROCESS CHARACTERISTICS, ENVIRONMENTAL DATA, AND CAPITAL COSTS}

\subsection{ANAEROBIC DIGESTION OF MUNICIPAL SLUDGE}

\subsubsection{Process Characteristics}

One of the advantages of anaerobic digestion is the simplicity of the processing equipment. The anaerobic sludge digestion plant consists of digesters and a filtration unit to dewater the digested sludge. Figure 2.1 is a flow diagram of the plant. As a basis for this plant model, a municipal center with population of about two million people was chosen. A conventional primary-secondary, activated-sludge digestion plant designed for $200 \times 10^{6}$ gallons per day (200 MGPD) -- 100 gallons per day per person -- is assumed to provide feedstock to the plant. The digestion plant will process 484,070 dry pounds of sludge per day, or $242 \mathrm{lb} /$ day per 1,000 people. The solids are assumed to be $75 \%$ volatile.11 Gas produced is medium-Btu (about $600 \mathrm{Btu} / \mathrm{ft}^{3}$ ), and, as suggested in Fig. 2.1, the model plant will burn a portion of the gas on site for internal power and heating needs. The balance of the gas, representing the net energy produced by the plant, will be used in the associated wastewater treatment plant. The energy production characteristics of the plant are summarized in Table 2.1. As shown there, 96 plants of this size could process sludge from 192 million people (if concentrated in suitably large cities) and produce 1 Quad (1015 Btu) of energy over a 20-year plant life.

Digesters. Thickened sludge from the wastewater treatment plant is fed to two-stage digesters at the rate of about 20,000 dry pounds per hour. The first stage is a complete-mix, high-rate digester, while the second stage further digests and decants the sludge. Volatile solids are reduced by

Table 2.1 Energy Production Characteristics of Anaerobic Digestion of Sludge in the As sumed System ${ }^{a}$

\begin{tabular}{lr}
\hline \multicolumn{1}{c}{ Characteristic } & Value \\
\hline Input, Btu/hr & $151.3 \times 10^{6}$ \\
Net Gas Output, Btu/hr & $59.4 \times 10^{6}$ \\
Efficiency, $\%$ & 39 \\
Overall life, years & 20 \\
Energy produced over 20 & $1.04 \times 10^{13}$ \\
years, Btu & \\
Number of plants to produce & 96 \\
$\quad$ Quad over 20 years & 192 \\
Population to feed 96 plants & $\times 10^{6}$ \\
\hline
\end{tabular}

aprocessing about 240 tons/day of sludge from a 200-MGPD waste-trearment plant. 


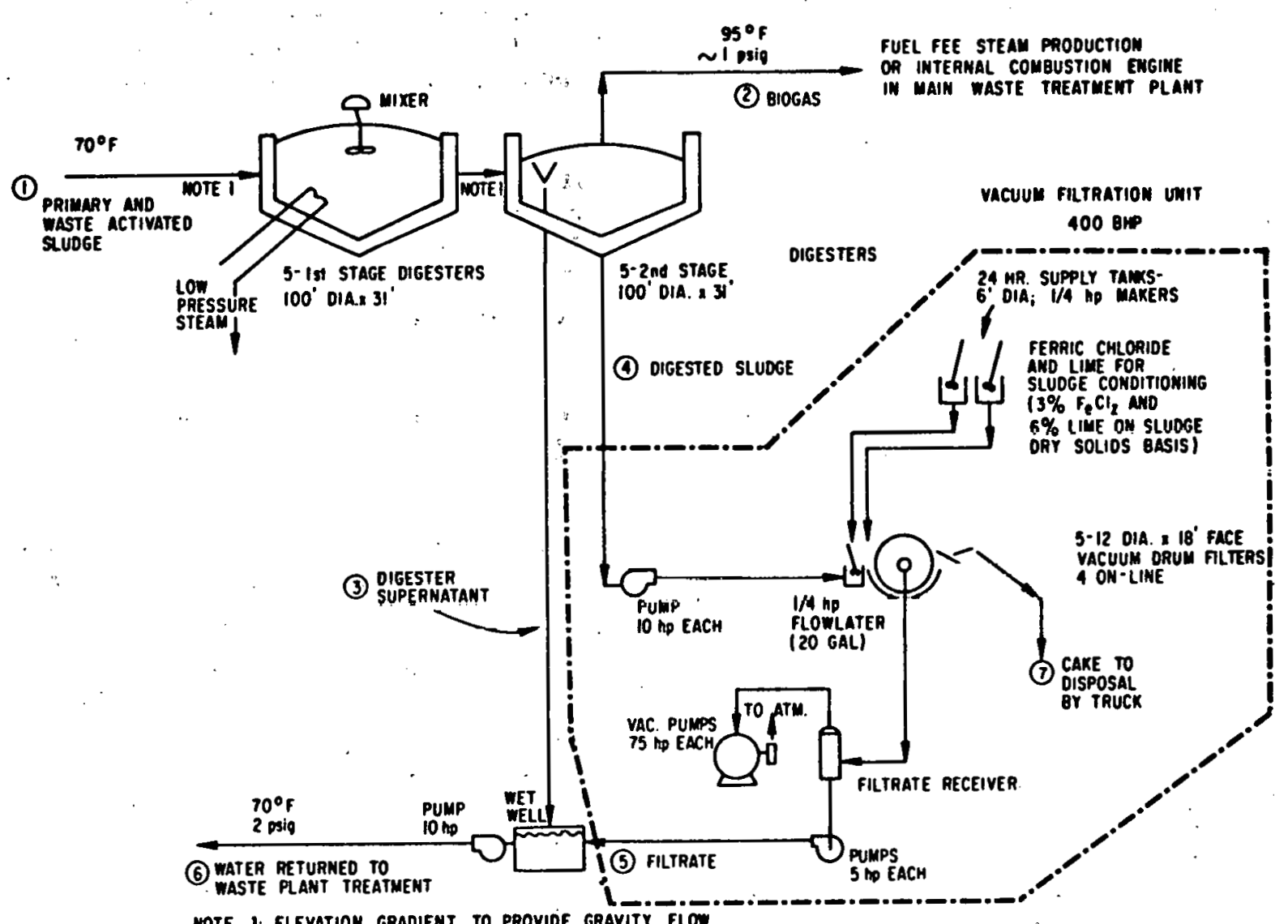

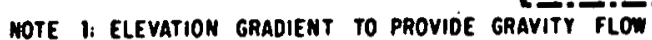

Fig. 2.1. Anaerobic Digestion of Municipal Sludge

\section{Stream Identification}

(1) Primary and Waste Activated Sludge--20,170 $\mathrm{tb} / \mathrm{hr}$ solids at 7 wt $\%$ solids, $75 \%$ volatile. Represents energy input of $151.3 \times 10^{6} \mathrm{Btu} / \mathrm{hr}$.

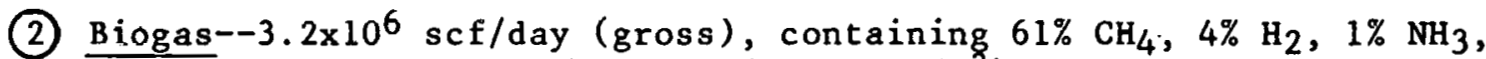
$0.5 \% \mathrm{H}_{2} \mathrm{O}, 0.5 \% \mathrm{O}_{2} ; 667 \mathrm{ppm} \mathrm{\textrm {H } _ { 2 } \mathrm { S }}\left(1,000 \mathrm{mg} / \mathrm{m}^{3}\right)$.

(3) Digester Supernatant- $-55,700 \mathrm{lb} / \mathrm{hr}$, containing $500 \mathrm{mg} / \mathrm{L} \mathrm{BOD}_{5}$ and 150 $\mathrm{mg} / \mathrm{L}$ suspented solids.

(4) nigested sludgens $11,840 \mathrm{lb} / \mathrm{hr}$ solids at $7 \mathrm{wt} \%$ sulids.

(5) Filtrate--122,700 $\mathrm{lb} / \mathrm{hr}$ containing $500 \mathrm{mg} / \mathrm{L}$ BOD 5 and $1,000 \mathrm{mg} / \mathrm{L}$ suspended solids.

6) Water Returned-- 3 p1us 5 .

(7) Cake--11,600 1b/hr solids at $25 \mathrm{wt} \%$ solids plus $34,8001 \mathrm{~b} / \mathrm{hr}$ of water.

Energy Penalties: Heating and mixing primary digesters: $0.66 \times 10^{6} \mathrm{scf} / \mathrm{day}$. Filter, operation at $10,000 \mathrm{Btu}$ per hp•hr: $0.16 \times 10^{6} \mathrm{scf} /$ day.

Net Biogas: $2.37 \times 10^{6} \mathrm{scf} / \mathrm{day}$. 
$55 \%$ in the process, yielding a gross gas production of $3.2 \times 10^{6} \mathrm{ft}^{3}$ of gas per day with a heating value of about $600 \mathrm{Btu} / \mathrm{ft}^{3}$. The digesters operate at about $95^{\circ} \mathrm{F}$, which requires the burning of about $5.25 \times 10^{5} \mathrm{ft}^{3}$ of the gas per day for heating.

Dewatering Filter. The digested sludge must be dewatered prior to final disposal. Sludge leaves the second stage digester at $6 \%$ solids by weight (wt \%). Solids content is increased to 25 wt \% by mechanical dewatering on a vacuum filtration device. The filtrate is returned to the water treatment plant, and the filter cake is collected and stored for ultimate disposal.

Materials. The amounts of steel and concrete required for all equipment in the plant are summarized in.Table 2.2 .

\subsubsection{Environmental Data}

Residuals and Effluents. The sulfur dioxide and.nitrogen oxide emissions listed in Table 2.3 are not emitted from the digestion process but from subsequent burning of the gas for steam production. Much of the carbon dioxide, however, is formed during the digestion reaction and passes through the system. Sulfur dioxide emissions are estimated to range from 16 to 32 $\mathrm{lb} / \mathrm{hr}$ : available data indicate a range of hydrogen sulfide $\left(\mathrm{H}_{2} \mathrm{~S}\right)$ of 1 to 2 grams per cubic meter of the digester gas. The high $\mathrm{H}_{2} \mathrm{~S}$ levels would be tolerable in steam boilers but may be corrosive in internal combustion motors, which might use digester gas at the treatment plant. The gas may therefore need scrubbing. The nitrogen oxide values were calculated from the assumed ammonia concentration in the biogas. 6

Water will leave the digestion system as decanted supernatant at the second digester and as filtrate from the dewatering filters. These streams will be returned to the head of the waste plant and therefore may not enter the environment, but suspended solids and biochemical oxygen demand in the water are nonetheless accounted for in Table 2.3.

The amounts of heavy metal residuals shown in Table 2.3 are calculated from the assumed feedstock composition, but actual sludge composition and heavy metal content are highly variable among areas. Table 2.4 illustrates the variability reported in three data sources; 2,12 the values chosen for this study are also indicated there.

Land and Water Use. About 5 acres of 1 and would be required for the plant. Water use is negative, because large quantities of water are recovered from the sludge and returned to the waste plant for-treatment. 
Table 2.3. Residuals from Anaerobic Digestion of 242 Tons/Day of Municipal Sludge Solids

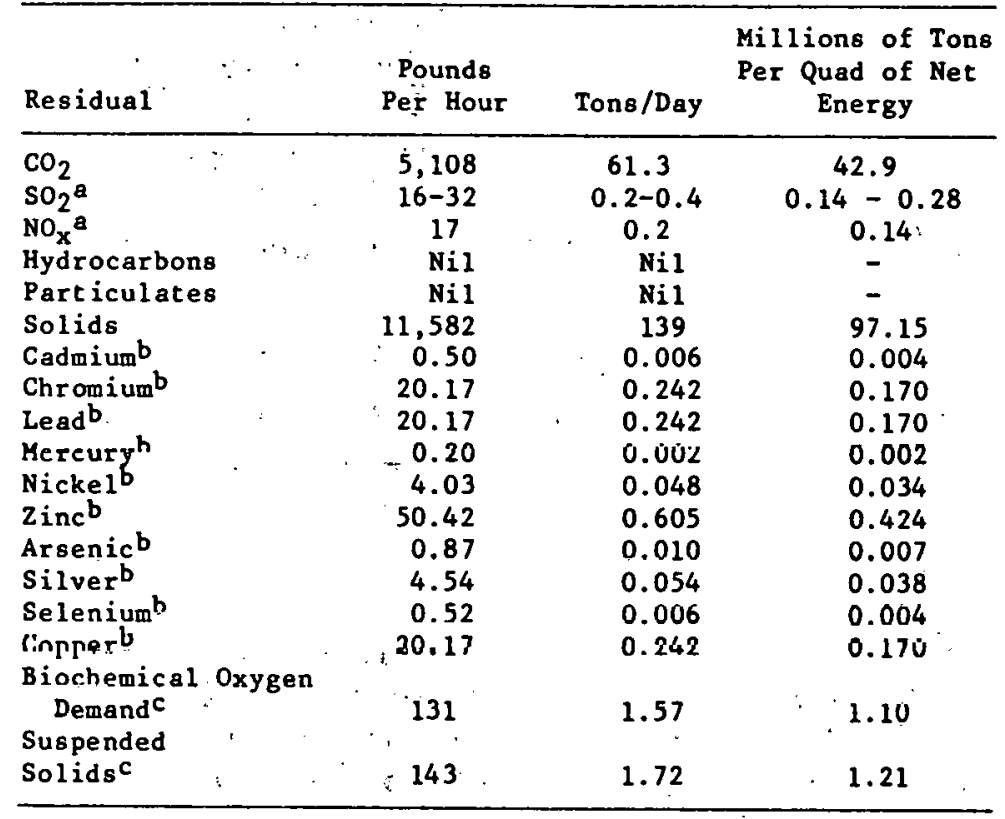

aFrom combustion of $\mathrm{H}_{2} \mathrm{~S}$ and $\mathrm{NH}_{3}$ in digester gas.

betals in solid residue.

cIn recovered water, which is returned to the waste plant for treatment.

Table 2.4. Reported Ranges and Means of Metal Concentrations (ppm) in Various Municipal Sludges

\begin{tabular}{|c|c|c|c|c|c|c|}
\hline \multirow[b]{3}{*}{ Metal } & \multirow[b]{2}{*}{ Co } & \multirow[b]{2}{*}{$\begin{array}{c}\vdots \\
\because \cdots\end{array}$} & \multirow{3}{*}{$\frac{\text { EPA }}{\text { Range }}$} & & \multicolumn{2}{|c|}{ Chaneyc } \\
\hline & & & & & \multirow{2}{*}{$\begin{array}{c}\text { Domest ic } \\
\text { Sludge } \\
\text { (Mean) }\end{array}$} & \multirow{2}{*}{$\begin{array}{l}\text { Concrolled } \\
\text { Municipal } \\
\text { Sludge } \\
\text { (Mean) }\end{array}$} \\
\hline & Range & Mcan & & Mean & & \\
\hline Arsenic & $6-230$ & $43^{-1}$ & $10-50$ & 9 & - & - \\
\hline Beryllium & $\dot{-}$ & - & e & $\mathbf{e}$ & - & - \\
\hline Cadmium & $3-3,410$ & 110 - & $0-1,100$ & 87 & 5 & $25^{d}$ \\
\hline Chromium & $10-99,000$ & 2,620 & $22-30.000$ & 1,800 & 50 & 1. , nood \\
\hline Copper & $84-10,400$ & - & - & - & - & $1,000^{d}$ \\
\hline Lead & $13-19,700$ & 1,360 & $80-26,000$ & 1,940 & 150 & $1,000^{d}$ \\
\hline Mercury & $0.2-10,600$ & 733 & $0.1-89$ & 7 & 2 & $10^{d}$ \\
\hline Nickel & $2-3,520$ & 320 & $0-2,800$ & 410 & 25 & $200^{d}$ \\
\hline Sel aniunu & $=$ & - & $10-180$ & $26^{d}$ & - & - \\
\hline Silver & - & - & $0-960$ & $225^{d}$ & - & - \\
\hline Zinc & $101-27,800$ & 2,790 & $51-28,360$ & 3,483 & 750 & $2,500^{d}$ \\
\hline
\end{tabular}

aef. 12.

bef. 20 .

cRef. 2 .

dValue assumed for feedstock sludge in this study.

eNot detected; beryllium content was assumed to be nil. 
Table 2.5. Contruction Costs for a-200-MGPD Anaerobic Sludge Digestion Plant

\begin{tabular}{|c|c|c|c|c|}
\hline \multirow[b]{2}{*}{ Component } & \multicolumn{4}{|c|}{ Cost in 1972 Dollars } \\
\hline & Materials & Transport & Labor & Tot al \\
\hline Digesters, Primary (5) & 432,500 & 16,500 & $1,093,500$ & $1,542,500$ \\
\hline Secondary (5) & 432,500 & 16,500 & $1,093,500$ & $1,542,500$ \\
\hline $\begin{array}{c}\text { Vacuum Filter and } \\
\text { Filter House }\end{array}$ & 595,550 & 20,660 & 343,790 & 960,000 \\
\hline Total & $1,460,550$ & 53,660 & $2,530,790$ & $4,045,000$ \\
\hline
\end{tabular}

\subsubsection{Capital Costs}

A little over $\$ 4$ million (1972 dollars) would be needed for materials, transportation, and labor to build an anaerobic digestion plant of the size assumed. Table 2.5 shows the components of this cost. (Estimates are expressed in 1972 dollars, as required for use in the SEAS mode1.)

\subsection{INCINERATION OF MUNICIPAL SLUDGE}

The composition of sludge to be incinerated is assumed to be the same as that assumed for anaerobic digestion in Section 1 and Tables 1.1 and 1.2. The plant size assumed is, however, larger by one-third than the digestion plant. Thus the incineration plant is assumed to proces municipal sludge from a population of about 3 million people.: .

Table 2:6. Energy Production Characteristics of Sludge Incineration in the Assumed Systema

\begin{tabular}{lc}
\hline Characteristic & Value \\
\hline Input, Btu/hr & $221.2 \times 10^{6}$ \\
Output, Btu/hr & $82.5 \times 10^{6}$ \\
Efficiency, \% & 37 \\
Overall life, years & 20 \\
Energy produced over 20 yearg, Btu & $1.45 \times 10^{13}$ \\
Number of plants to produce 1 Quad & 69 \\
over 20 years & $207 \times 10^{6}$ \\
Population to feed 69 plants &
\end{tabular}

aprocessing sludge from a 300-MGPD waste-treatment plant. 


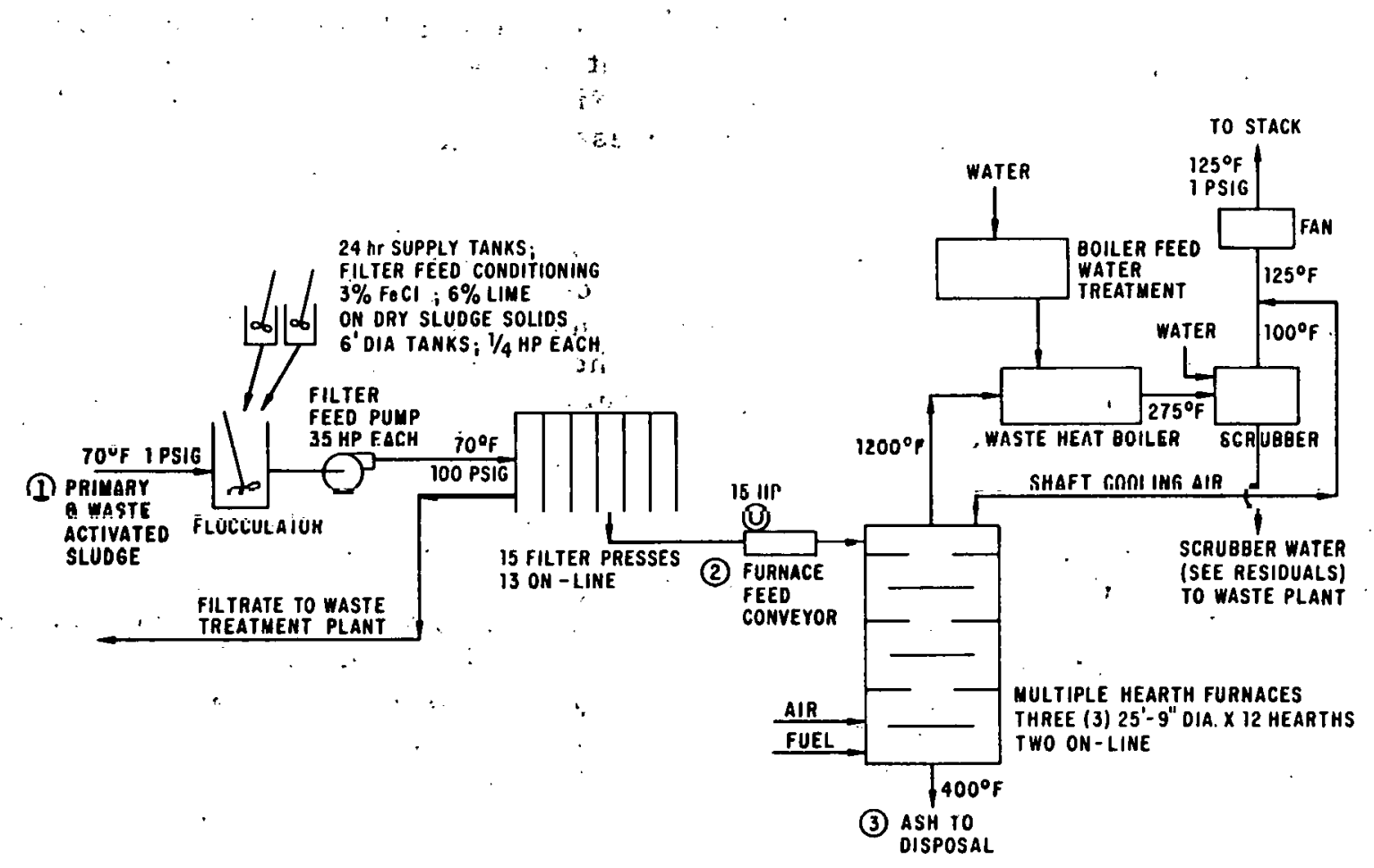

Fig. 2.2. Incineration of Municipal Sludge.

Stream Identification

(1) Primary and Waste Activated Sludge--29,500 lb/hr solids at 5 wt\% solids; $75 \%$ volatile. Represents energy input of $221.2 \times 10^{6}$ $\mathrm{Btu} / \mathrm{hr}$.

(2) Furnace Feed- $-30,250 \mathrm{lb} / \mathrm{hr}$ solids at 30 wt solids, containing

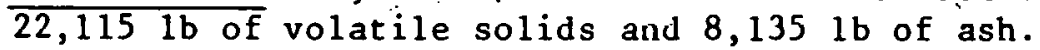

(3) Ash--9;000 1b/hr.

Energy Penalties: Furnace heating: 800 bhp.

Filter operation: 650 bhp.

Miscellaneous lnsses: 150 hhp.

Net Energy Recovered: $82.5 \times 10^{6} \mathrm{Btu} / \mathrm{hr}$. 


\subsubsection{Process Characteristics}

Processing units for the sludge incineration system include dewatering filters, multiple-hearth furnaces, waste heat boilers, and flue gas scrubbers. A flow diagram of these units is shown in Fig. 2.2. The energy characteristics of the model incineration plant are presented in Table 2.6 (p.11).

Dewatering Filters. Filter presses are assumed to be used for dewatering. The filters increase the solids content of the sludge from about 4 wt \% to $30 \mathrm{wt} \%$. Ferric chloride and calcium hydroxide are added to the sludge before dewatering to aid in filtering. The sludge is dewatered to produce about 30,000 pounds of dry solids per hour, which requires 13 presses and about 650 brake horsepower.

Incinerators. Dewatered sludge enters the top hearth of the multiplehearth furnace, where it is dried by hot combustion gases coming from the lower hearths. Sludge is burned as it moves downward through the hearths. Three multiple-hearth furnaces are required (one is held in reserve to allow an increase in operation when necessary). Each furnace has 12 stacked hearths with an internal diameter of 25.75 feet. To insure efficient burning, air is supplied at $75 \%$ above the stoichiometric requirement. To achieve a flue gas temperature of $1200^{\circ} \mathrm{F}$, fuel is required at a rate equivalent to about $25.5 \mathrm{x}$ $10^{6}$ Btu per hour.

Waste Heat Boiler. Heat energy is recovered from the incinerator combustion gas in a waste-heat boiler at the rate of 89,000 pounds of steam per hour, at $700^{\circ} \mathrm{F}$ and $600 \mathrm{psi}$. The combustion gases are simultaneously cooled to about $200^{\circ} \mathrm{F}$.

Scrubber.. Multiple-hearth incinerators typically emit about 33 pounds of solids per ton of dry sludge feed.6 These particulates are controlled by wet scrubbing in a venturi scrubber, which reduces particulates in the flue gas by $96 \%$. Particulate emission is thus reduced to about 1.3 pounds of solids per ton of dry sludge feed. The scrubbed flue gas is mixed with air that has cooled the incinerator and passed to the stack, where it is released to the atmosphere.

Materials. The amounts of steel, polyropylene (for the filter presses), concrete, and bricks required for construction of the incineration plant are sumnarized in Table 2.7.

\subsubsection{Environmental Data}

Residuals and Effluents. Operating wastes given in Table 2.8 are based on the feedstock characteristics described in Tables 1.1 and 1.2. Distribution of heavy metals in scrubber water, stack effluent, and ash is given in Table 2.9 . 
Table 2.7. Amounts of Materials Required for the Sludge Incineration Plant Assumeda

\begin{tabular}{|c|c|c|c|c|c|}
\hline Component & $\begin{array}{l}\text { Steel } \\
\text { Tons }\end{array}$ & $\begin{array}{l}\text { Polypro- } \\
\text { pylene, } \\
\text { Tons }\end{array}$ & $\begin{array}{l}\text { Concrete, } \\
\text { Yards }\end{array}$ & $\frac{\text { Bri }}{\text { Refractory }}$ & $\frac{\text { ks, Tons }}{\text { Insulating }}$ \\
\hline $\begin{array}{l}\text { Filter } \\
\text { Presses (15) }\end{array}$ & 675 & 225 & - & - & - \\
\hline $\begin{array}{l}\text { Filter } \\
\text { Building }\end{array}$ & 86 & - & 266 & - & - \\
\hline $\begin{array}{l}\text { 12-Hearth } \\
\text { Furnaces }\end{array}$ & 2,800 & - & 285 & 2,154 & 1,158 \\
\hline Total & 3,561 & 225 & 551 & 2,154 & 1,158 \\
\hline
\end{tabular}

aprocessing municipal sludge from a 300-MGPD waste-treatment plant.

Table 2.8. Residuals from. Incineration of 354 Tons/Day of Municipal Sludge Solids

\begin{tabular}{|c|c|c|c|c|}
\hline Residual & & $\begin{array}{l}\text { Pounds } \\
\text { per/hour }\end{array}$ & Tons/Day & $\begin{array}{c}\text { Millions of Tons } \\
\text { per Quad of Net } \\
\text { Energy }\end{array}$ \\
\hline $\mathrm{CO}_{2}$ & & 41,235 & 495 & 250 \\
\hline $\mathrm{SO}_{2} \mathrm{a}^{\mathrm{a}}$ & & 35.2 & 0.422 & 0.21 \\
\hline${ }^{\mathrm{NO}}{ }_{x}{ }^{a}$ & & 70.3 & 0.844 & 0.43 \\
\hline Hydrocarbons & - & Ni 1 & Nil & Ni 1 \\
\hline Particulates & & 19.2 & 0.230 & 0.12 \\
\hline Ash & & 8,982 & 107.8 & 54.4 \\
\hline Cadmi um & & 0.72 & 0.009 & 0.0045 \\
\hline Chromium & & 29.0 & 0.348 & 0.174 \\
\hline Lead & & 29.0 & 0.348 & 0.174 \\
\hline Mercury & & 0.29 & 0.003 & 0.0018 \\
\hline Nickel & & 5.76 & 0.069 & 0.035 \\
\hline Zinc & & $72: 6$ & 0.871 & 0.435 \\
\hline Arsenic & & 1.24 & 0.015 & 0.0073 \\
\hline Silver & & 6.54 & 0.078 & 0.039 \\
\hline Selenium & & 0.76 & 0.009 & 0.0047 \\
\hline Copper & & 29.0 & 0.348 & 0.174 \\
\hline
\end{tabular}

astimated from EPA stack tests. 
Table 2.9. Distribution of Metals in SludgeIncineration Wastes, Per Quad of Energy Produced

\begin{tabular}{|c|c|c|c|c|}
\hline Metal & $\begin{array}{l}\text { Amount in } \\
\text { Scrubber } \\
\text { water }\end{array}$ & $\begin{array}{c}\text { Waste, } \\
\begin{array}{c}\text { Stack } \\
\text { gas }\end{array}\end{array}$ & $\begin{array}{c}\text { Thous ands } \\
\text { Ash }\end{array}$ & of Tons \\
\hline $\begin{array}{l}\text { Arsenic } \\
\text { Cadmium } \\
\text { Chromium } \\
\text { Copper } \\
\text { Lead } \\
\text { Mercury } \\
\text { Nickel } \\
\text { Selenium } \\
\text { Silver } \\
\text { Zinc }\end{array}$ & $\begin{array}{r}1.7 \\
3.2 \\
9.3 \\
9.7 \\
8.6 \\
1.4 \\
7.9 \\
1.0 \\
8.9 \\
195.7\end{array}$ & $\begin{array}{r}0.2 \\
0.4 \\
4.5 \\
4.5 \\
8.9 \\
0.2 \\
0.9 \\
0.1 \\
1.0 \\
21.7\end{array}$ & $\begin{array}{r}5.4 \\
0.9 \\
130.4 \\
129.3 \\
86.7 \\
0.2 \\
25.9 \\
3.6 \\
29.5 \\
217.1\end{array}$ & $\begin{array}{r}7.3 \\
4.5 \\
174.2 \\
173.5 \\
174.2 \\
1.8 \\
34.7 \\
4.7 \\
39.4 \\
434.5\end{array}$ \\
\hline
\end{tabular}

Land and Water Use. As in the case of the anaerobic digestion plant, it is assumed that the incineration plant would be constructed near an existing municipal waste treatment facility. About one acre of 1 and would be needed, and water use would be negative: large amounts of water would be returned to the waste plant for treatment.

\subsubsection{Capital Costs}

The capital cost of building an incineration plant that would process municipal sludge from 3 million people totals $\$ 14,512,500$ (1972 dollars). Table 2.10 shows the components of this cost.

Table 2.10. Construction Costs for a 300-MGPD

Sludge Incineration Plant

\begin{tabular}{lrrrr}
\hline & \multicolumn{4}{c}{ Cost in 1972 Dollars } \\
\cline { 2 - 5 } Component & Materials & Transport & Labor & Total \\
\hline Multiple-Hearth & & & & \\
$\quad$ Furnaces (3) & $2,439,780$ & 121,680 & $4,851,870$ & $7,413,330$ \\
Filter Presses (15) & $4,350,000$ & 217,200 & $1,102,500$ & $5,669,700$ \\
Filtcr House & 120,000 & 10,000 & 60,000 & 190,000 \\
Waste-Heat & 446,000 & 25,770 & 357,750 & 829,520 \\
$\quad$ Boilera & 38,950 & 2,000 & 44,000 & 84,950 \\
Scrubber & 195,700 & 10,300 & 119,000 & 325,000 \\
Stack & $7,590,430$ & 386,950 & $6,535,120$ & $14,512,500$ \\
Total & & & &
\end{tabular}

ancluding equipment for feed-water treatment. 

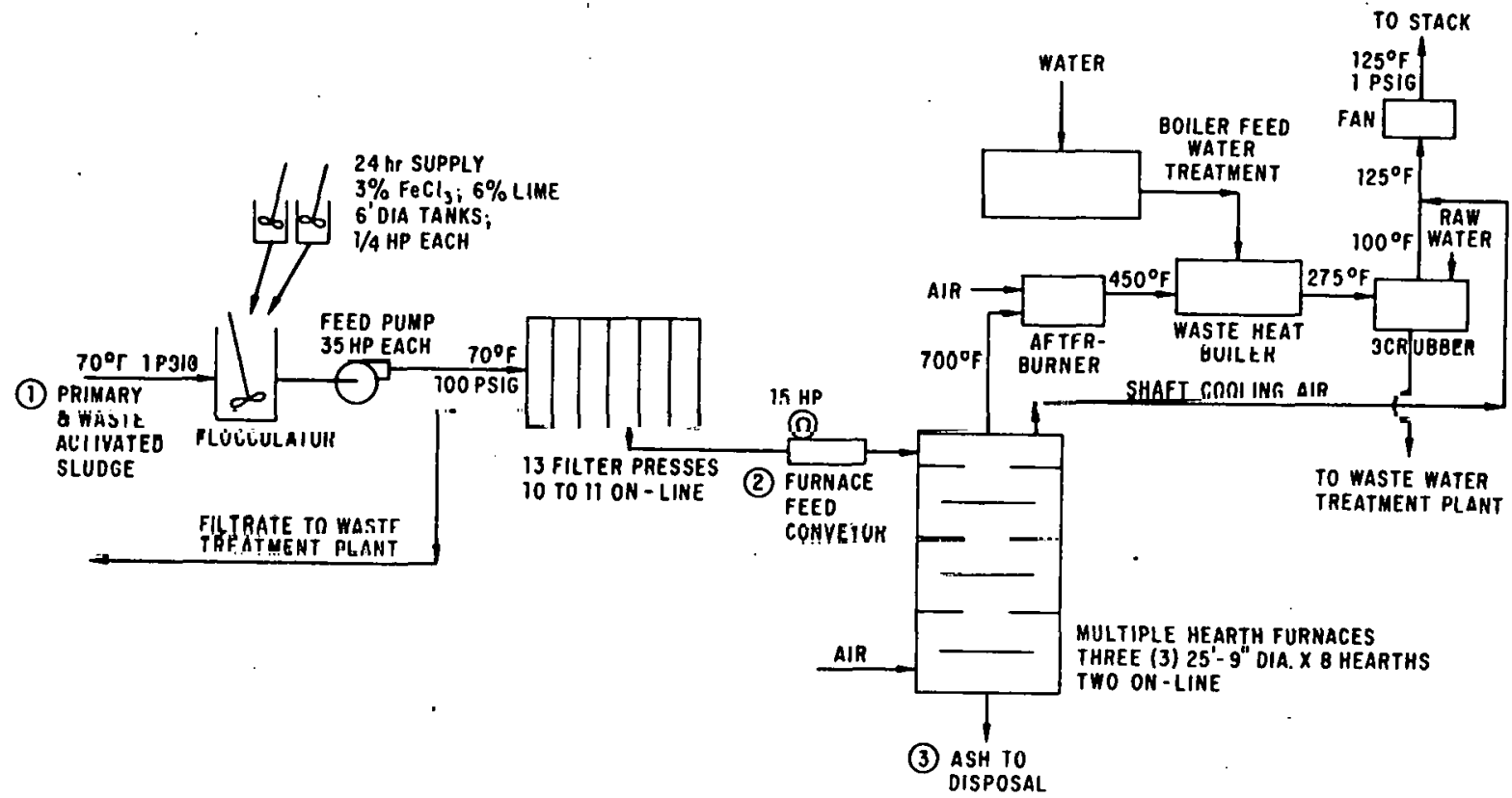

Fig. 2.3. Pyrolysis of Municipal Sludge

\section{Stream Identification}

(1) Primary and Waste Activated Waste Sludge--29,500 1b/hr solids at 5 wt \% solids, $75 \%$ volatile. Represents energy input of $22 \mathrm{i} .2 \mathrm{x}$ $10^{6} \mathrm{Btu} / \mathrm{hr}$.

(2) Furnace Feed--30,250 1b/hr solids at $35 \mathrm{wt} \%$ solids, containing $22,1151 \mathrm{~b}$ of volatile solids and $8,135 \mathrm{lb}$ of ash.

(3) Ash- $-9,0001 \mathrm{~b} / \mathrm{hr}$.

Energy Penalty: Equivalent to 1,380 bhp.

Net Energy Recovered: $104.6 \times 10^{6} \mathrm{Btu} / \mathrm{hr}$. 


\subsection{PYROLYSIS OF MUNICIPAL SLUDGE}

\subsubsection{Process Characteristics}

Pyrolysis requires a sludge dewatering unit (filter presses), a pyro1ysis reactor, a fuel gas afterburner, a waste heat boiler, and a flue gas scrubber. Such a system is being installed in Contra Costa County, California.12 The process flow diagram in Fig. 2.3 shows the arrangement of these units. The fuel gas produced is immediately burned in an afterburner to produce medium-pressure $(600 \mathrm{psig})$ steam, the energy content of which represents the energy yield of the process.

Nearly $47 \%$ of the energy content of sewage sludge is recovered for use in the water treatment plant. It is estimated that sludge produced by a population of $165 \mathrm{milli}$ on people could produce a Quad of energy over 20 years, but because of the distribution of population, only $30 \%$ of this energy is economically recoverable. Energy production by pyrolysis is summarized in Table 2.11.

Dewatering Unit. Wet sludge is dewatered by pressure filtration to increase the solids content of the sludge from 5 wt $\%$ to 35 wt \%. About 504,000 pounds of water per hour are rejected from the sludge. Thirteen filter presses, including two or three as spares, are required; the on-line power required for the filter process amounts to 530 brake horsepower.

Pyrolysis Reactor. Multiple-hearth furnaces similar to those used for incineration serve as pyrolysis reactors. The controllability and combustion efficiency of such furnaces are enhanced in this use as partial-combustion reactors.

Table 2.11: Energy Production Characteristics of Sludge Pyrolysis in the Assumed Systema

\begin{tabular}{lc}
\hline \multicolumn{1}{c}{ Characteristic. } & Value \\
\hline $\begin{array}{l}\text { Input, Btu/hr } \\
\text { Output, Btu/hr }\end{array}$ & $221.2 \times 10^{6}$ \\
Efficiency, \% & $104.6 \times 10^{6}$ \\
Overall life, years & 47 \\
Energy produced over 20 \\
years, Btu \\
$\begin{array}{l}\text { Number of plants to produce } \\
\text { l quad over 20 years }\end{array}$ \\
$\begin{array}{l}\text { Population to feed } \\
55 \text { plants. }\end{array}$ \\
\hline $\begin{array}{l}\text { aprocessing sludge from a 300-MGPD waste-treatment } \\
\text { Plant. }\end{array}$
\end{tabular}


The plant contains three furnaces, one of which is kept in reserve. Each has nine refractory hearths surrounded by an insulated steel shell about 23 feet in diameter. A rotating central shaft, cooled by air, bears rabble arms to mix the sludge with the hot gases and move it to the ports opening into the next-lower hearth. The temperature in the top hearths may be as low as $600^{\circ} \mathrm{F}$, while the bot tom hearths operate at about $1,500^{\circ} \mathrm{F}$.

Dewatered sludge enters the furnaces at about $35 \mathrm{wt} \%$ solids, at a feed rate of 86,440 lb (wet) per hour; the fuel gas produced has a heating value between 100 and $150 \mathrm{Btu} / \mathrm{ft}^{3}$ - rather low, because of the high content of nitrogen, water vapor, and carbon dioxide in the gas. This gas passes direct1y to the afterburner for energy production.

Fuel Gas Afterburner. The pyrolysis gas produced in the furnace is ignited in an afterburner, which increases the gas temperature from $825^{\circ} \mathrm{F}$ to $1,243^{\circ} \mathrm{F}$. Air is fed to the afterburner in $40 \%$ excess over the stoichiometric amount required for combustion of the volatile solids in the sludge.

Waste Heat Boiler. Hot gases frum the afcerburner raise steam in a waste heat boiler -- about 88,000 pounds of steam per hour at 600 psig and $700^{\circ} \mathrm{F}$. This steam represents a heat recovery rate of $113 \times 10^{6}$ Btu per hour. The plant consumes about $8 \times 10^{6}$ Btu per hour, resulting in a net yield of $47 \%$ of the energy contained in the original sludge.

Scrubber. This type of multiple-hearth furnace, when operated in the incineration mode, emits in the gas 33 pounds of solids per ton of feed. No data on emissions in the pyrolysis mode are available; the emission rate should be lower than from incineration, but presumably some solids will still be emitted. Therefore the flue gases from the afterburner must be scrubbed to remove about $96 \%$ of the solid particles, reducing the solid emissions to less than 1.3 pounds per ton of dry sludge. To accomplish this, the gas is put through a venturi scrubber operated at a pressure drop of about 20 inches of watcr.

Materials. Material requirements are summarized in Table 2.12.

\subsubsection{Environmental Data}

Residuals and Effluents. Residuals from sludge pyrolysis in a plant of the size assumed are summarized in Table 2.13. The distribution of metals between the ash, scrubber water, and flue gas is shown in Table 2.14. Emissions to air come from the afterburner. Nitrogen oxide emissions were calculated from daca on nitrogen oxides produced from low- and medium-Btu gases. Sulfur dioxide emissions are based on EPA tests of sludge incineration facilities and the Contra Costa County, California, tests, 16 which indicate that only a small percentage of the sludge sulfur is oxidized.

Land and Water Use. It is estimated that one acre of land would be required for the plant. Water use would be minimal or negative, as with the other processes discussed. 
Table 2.12. Amounts of Materials' Required for the Sludge Pyrolysis Plant Assumeda

\begin{tabular}{lccccc}
\hline $\begin{array}{c}\text { Unit } \\
\text { Operation }\end{array}$ & $\begin{array}{c}\text { Steel, } \\
\text { Tons }\end{array}$ & $\begin{array}{c}\text { Poly- } \\
\text { propylene, } \\
\text { Tons }\end{array}$ & $\begin{array}{c}\text { Concrete, } \\
\text { Yards }\end{array}$ & Refractory & Insulating \\
\hline $\begin{array}{c}\text { Filter } \\
\text { Presses } \\
\quad(13)\end{array}$ & 585 & 195 & - & - & - \\
$\begin{array}{c}\text { Filter } \\
\text { Building }\end{array}$ & 85 & - & 230 & - & - \\
$\begin{array}{c}\text { 8-Hearth } \\
\text { Furnaces } \\
(3)\end{array}$ & 1,869 & - & 180 & 1,440 & 771 \\
$\begin{array}{c}\text { Total } \\
\text { Total }\end{array}$ & 2,529 & 195 & 410 & 1,440 & 771 \\
\hline
\end{tabular}

aProcessing municipal sludge from a 300-MGPD waste-treatment plant.

Source: Refs. 13, 14 .

Table 2.13. Residuals from Pyrolysis of Sludge from a 300 MGPD Treatment Plant

\begin{tabular}{|c|c|c|c|}
\hline Residual & $\begin{array}{l}\text { Pounds } \\
\text { per Hour }\end{array}$ & Tons/day & $\begin{array}{c}\text { Millions of Tons } \\
\text { per Quad of } \\
\text { Energy }\end{array}$ \\
\hline $\mathrm{CO}_{2}$ & 37,097 & 445 & 177.3 \\
\hline $\mathrm{SO}_{2}{ }^{\mathrm{a}}$ & 35.2 & 0.422 & 0.17 \\
\hline $\mathrm{NO}_{\mathrm{x}} \mathrm{b}$ & 48.2 & 0.578 & 0.23 \\
\hline Hydrocarbons & $\mathrm{Nil}$ & $\mathrm{Nil}$ & $\mathrm{Nil}$ \\
\hline Particulates & 19.2 & 0.230 & 0.10 \\
\hline Ash & 8,982 & 107.8 & 42.9 \\
\hline Cădüium & 0.74 & 0.009 & 0.0035 \\
\hline Chromium & 29.49 & 0.354 & 0.141. \\
\hline Lead & 29.49 & 0.354 & 0.141 \\
\hline Mercury & 0.29 & 0.004 & 0.0014 \\
\hline Nicke1 & 5.90 & 0.071 & 0.028 \\
\hline Zinc & 73.72 & 0.885 & 0.352 \\
\hline Arsenic & 1.27 & 0.015 & 0.0061 \\
\hline Silver & 6.63 & 0.080 & 0.032 \\
\hline Selenium & 0.77 & 0.009 & 0.0037 \\
\hline Copper & 29.49 & 0.354 & 0141 \\
\hline
\end{tabular}

astimated from EPA stack tests.

bCalculated. 


\subsubsection{Capital Costs}

The capital costs of building a pyrolysis system to process municipal sludge from 3 million people total $\$ 11,211,410$ (1972 dollars). Table 2.15 presents the cost breakdown for the pyrolysis unit.

Table 2.14. Distribution of Metals in SludgePyrolys is Wastes, Per Quad of Energy: Produced

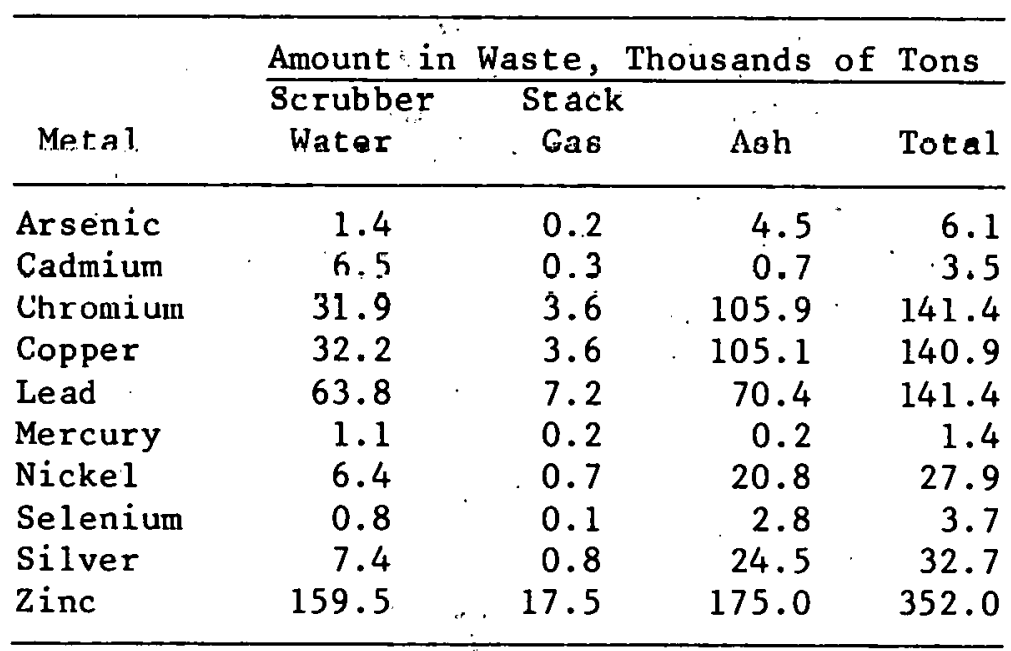

Source: Refs. $2,151$. .

Table 2.15 Construction Costs for a 300-MGPD Sludge Pyrolysis Plant

\begin{tabular}{lrrrr}
\hline & & Cost in 1972 & Dollars & \\
\cline { 2 - 5 } Component & Materials & Transport & Labor & Total \\
\hline Filter Presses (13) & $3,770,000$ & 188,500 & 955,500 & $4,914,000$ \\
Filter House & 120,000 & 10,000 & 60,000 & 190,000 \\
Multiple-Hearth & & & & \\
$\quad$ Furnaces (3) & $1,829,850$ & 91,260 & $3,414,000$ & $5,335,110$ \\
Afterburner & 284,400 & 14,900 & 202,700 & 502,000 \\
Scrubber & 30,900 & 1,600 & 31,800 & 64,300 \\
Stack & 132,500 & 7,000 & 66,500 & 206,000 \\
Total & $6,167,650$ & 313,260 & $4,730,500$ & $11,211,410$ \\
& & & & \\
\hline
\end{tabular}




\section{MANURE-CONVERSION SYSTEMS: PROCESS CHARACTERISTICS, ENVIRONMENTAL DATA, AND CAPITAL COSTS}

As discussed in the Introduction, beef cattle at an average weight of 1,000 pounds produce 60 pounds of $\mathrm{raw}$ manure per head per day, containing 6.9 pounds of total solids, of which 5.9 pounds is volatile solids. Major beefproducing regions in the United States may have cattle populations in the range from. 200,000 to 800,000 head within a 50-mile radius. 5 In such regions, therefore, it would be possible to collect manure from about 145,000 cattle with an average haul distance of 25 miles. An anaerobic digestion system could draw on such a large supply of feedstock, but smaller systems would also be feasible: the one described below would process manure from 25,000 cattle. In contrast, pyrolysis systems are more capital intensive and offer economies of scale, particularly in the costs of pollution control equipment. Therefore the pyrolysis system to be described is scaled for the manure output of 145,000 cattle.

\subsection{ANAEROBIC DIGESTION OF FEEDLOT MANURE}

\subsubsection{Process Characteristics}

The assumed design of an anaerobic digestion plant for feedlot manure is based primarily on the flowsheet (Fig. 3.1) developed by Bio Gas of Colorado, Inc. 10 This plant can process $0.2 \mathrm{lb} /$ day of volatile solids per cubic foot of digester capacity. At $5.9 \mathrm{lb}$ of volatile solids per day per animal, 25,000 head of cattle will produce 147,500 lb of volatile solids, which will require $737,500 \mathrm{ft}^{3}$ of digester capacity. This capacity is supplied by three primary digesters 100 feet in diameter by 31 feet high. Three secondary digesters of the same size, with gas-holding covers, are also needed.

The digested sludge ( 42.5 tons of dry solids per day) is dewatered by 110-horsepower centrifuges, 17 two on line and one in reserve: The extracted water goes to a controlled algae pond and later is returned to mix with raw manure entering the plant. The algae are harvested and dried as an animal feed supplement; the dewatered, digested residue is used as a fertilizer additive or solar-dried for animal feed.

Assuming a biogas production of 8.5 cubic feet per pound of volatile solids, this digestion plant would produce a gross yield of $1.25 \times 10^{6}$ cubic feet of gas per day. ${ }^{3}$ The digester gas is purified in an amine absorption step (see Fig. 3.1) to remove $35 \%$ of the $\mathrm{CO}_{2}$ and most of the ammonia and hydrogen sulfide, resulting in gas with a heating value of $710 \mathrm{Btu} / \mathrm{ft}^{3}$. Although gas with this much $\mathrm{CO}_{2}$ is not pipeline quality, it can be mixed with natural gas as an energy supplement. Removing more $\mathrm{CO}_{2}$ by absorption could produce pipeline-quality gas, but the additional purification would consume much more energy. Removal of $35 \%$ of the $\mathrm{CO}_{2}$ consumes $3.1 \times 10^{6} \mathrm{Btu} /$ hr, which represents $10 \%$ of the total gas produced. (In some cases, it may. be feasible to remove more $\mathrm{CO}_{2}$. For example, Bio Gas, Inc. plans $50 \% \mathrm{CO}_{2}$ removal for a facility in Lamar, Colorado.) 


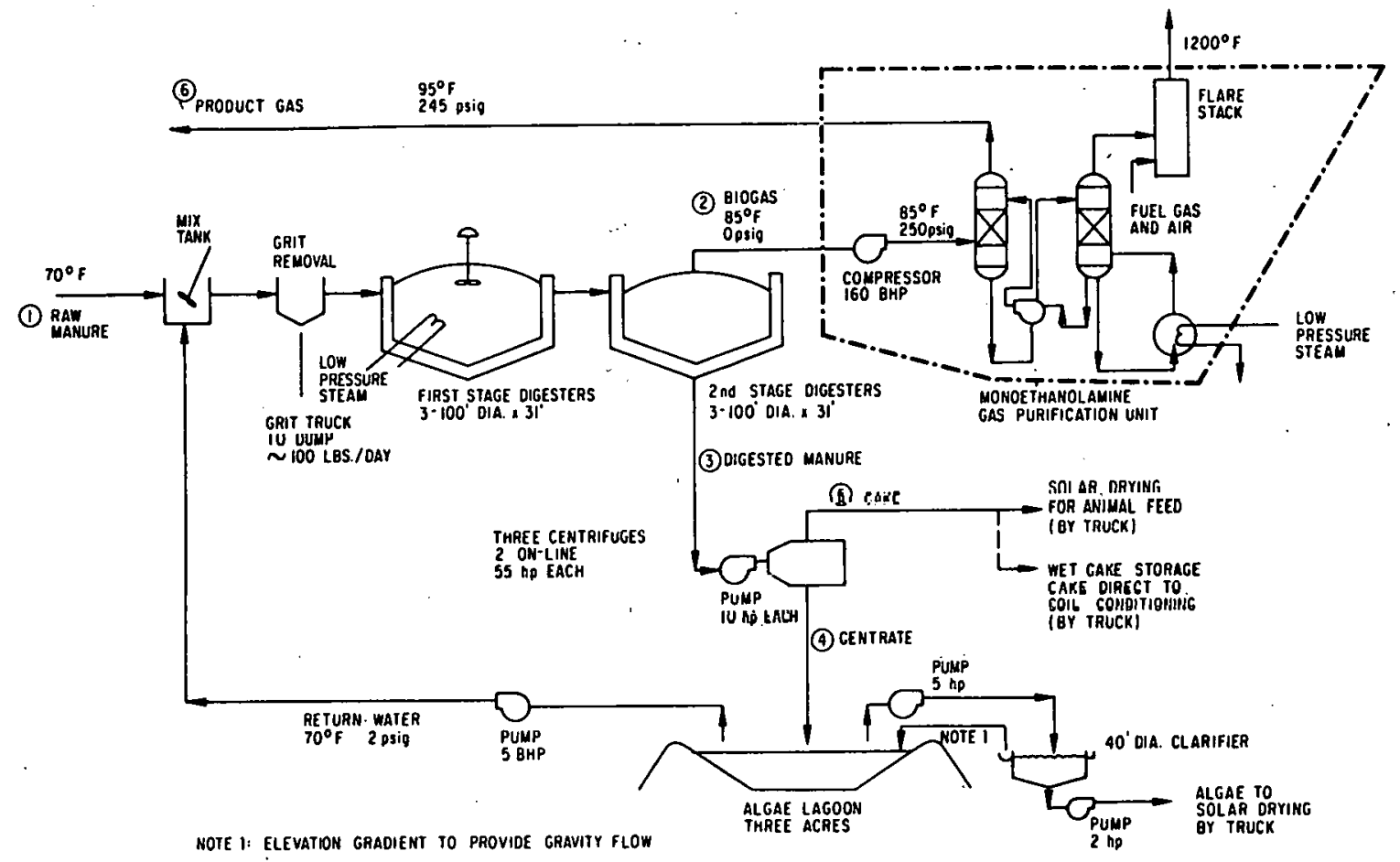

Fig. 3.1. Anaerobic Digestion of Manure

\section{Stream Identification}

(1) Raw Manure--62,500 1b/hr at 11.5 wt\% solids $(7,188 \mathrm{lb} / \mathrm{hr}$ total solids) containing 6,125 lb volatile solids.

(2) Biogas- $-1.25 \times 10^{6} \mathrm{scf} /$ day $\left(8.5 \mathrm{ft}^{3} / 1 \mathrm{~b}\right.$ of volatile solids), containing $60 \% \mathrm{CH}_{4}, 38 \% \mathrm{CO}_{2}, 1 \% \mathrm{H}_{2} \mathrm{~S}, 1 \% \mathrm{NH}_{3}$. Gross gas heating value is $31.25 \times 10^{6} \mathrm{Btu} / \mathrm{hr}$.

(3) Digested Manure--3,542 1b/hr solids at 4 wt $\%$ solids.

(4) Centrate--177 lb/hr of solids.

(5) Coke--3,365 1b/hr solids at $25 \mathrm{wt} \%$ solids.

(6) Product Gas $-71 \% \mathrm{CH}_{4}, 29 \% \mathrm{CO}_{2} ;$ contiains $710 \mathrm{Btu} / \mathrm{sGf}$.

Energy Penalties: Heating and mixing primary digester: $10 \times 10^{6} \mathrm{Btu} / \mathrm{hr}$ Centrifuge operation: $1.1 \times 10^{6} \mathrm{Btu} / \mathrm{hr}$

Gas purification: $3.1 \times 10^{6} \mathrm{Btu} / \mathrm{hr}$

Net Energy Recovered: $17.1 \times 10^{6} \mathrm{Btu} / \mathrm{hr}$; efficiency $28 \%$. 
Other major energy penalties within the digestion plant include $1.1 \mathrm{x}$ $10^{6} \mathrm{Btu} / \mathrm{hr}$ for the centrifuges and $10 \times 10^{6} \mathrm{Btu} / \mathrm{hr}$ for heating and mixing the primary digesters. Net energy production is $17.1 \times 10^{6} \mathrm{Btu} / \mathrm{hr}$, a $28 \%$ efficiency overall. The net energy output from 25,000 head of cattle is roughly equivalent to $410,000 \mathrm{ft}^{3}$ of natural gas per day. Energy production from the plant is summarized in Table 3.1 .

Materials. The construction materials required are shown in Table 3.2 , on the basis of construction practices common in municipal waste treatment.

Table 3.1. Energy Production Characteristics of Anaerobic Digestion of Manure in the As sumed Systema

\begin{tabular}{ll}
\hline \multicolumn{1}{c}{ Characteristic } & \multicolumn{1}{c}{ Value } \\
\hline Input (Feedstock), Btu/hr & $61.5 \times 10^{6}$ \\
Ancillary Input, Btu/hr & $14.2 \times 10^{6}$ \\
Energy Production, Gross Btu/hr & $31.3 \times 10^{6}$ \\
Energy Production, Net Btu/hr & $17.1 \times 10^{6}$ \\
Efficiency, \% & 28 \\
Overall life, years & 20 \\
Energy produced over 20 years, Btu & $0.30 \times 10^{13}$ \\
Number of plants to produce & 333 \\
1 Quad over 20 years & $8.32 \times 10^{6}$ \\
Cattle to feed 333 plants & \\
Gas Composition: & 71 \\
Methane, vo1. $\%$ & 29 \\
Carbon Dioxide, vol. \% & \\
\hline arocessing $1.5 \times 10^{6}$ pounds of raw manure per \\
day from 25,000 cattle.
\end{tabular}

Table 3.2. Amounts of Materials Required for the Manure Digestion Plant As sumeda

\begin{tabular}{lccc}
\hline \multicolumn{1}{c}{ Components } & $\begin{array}{c}\text { Steel, } \\
\text { Tons }\end{array}$ & $\begin{array}{c}\text { Stainless } \\
\text { Steel, } \\
\text { Tons }\end{array}$ & $\begin{array}{c}\text { Concrete, } \\
\text { Yards }\end{array}$ \\
\hline $\begin{array}{l}\text { Digesters } \\
\text { Centrifuges (3) }\end{array}$ & 600 & - & 4800 \\
$\begin{array}{l}\text { Centrifuge } \\
\text { Building }\end{array}$ & 4 & 7 & - \\
$\begin{array}{l}\text { Auxilliary Equip. } \\
\text { Gas Purifiers }\end{array}$ & 19 & - & 125 \\
Total & 2.3 & - & - \\
\hline
\end{tabular}

a Processing manure from 25,000 cattle. 
Concrete tanks with steel covers are usually used, but Bio Gas of Colorado, Inc. is considering earthern basins lined with plastic, which should be appreciably less expensive.

\subsubsection{Environmental Data}

Residuals and Effluents. Table 3.3 summarizes the waste products from the anaerobic digestion plant. The only emissions to air are in the waste gas from regenerator off-gas. This gas contains $\mathrm{CO}_{2}, \mathrm{SO}_{2}$, and some $\mathrm{NO}_{\mathrm{x}}$; the amounts of $\mathrm{SO}_{2}$ and $\mathrm{NO}_{\mathrm{x}}$. shown in the table are calculated on an assumed concentration of $1 \% \mathrm{H}_{2} \mathrm{~S}$ and $1 \% \mathrm{NH}_{4}$ in the raw biogas. 11 The $\mathrm{CO}_{2}$ is simply stripped from the biogas.

The quantities of metals shown as residuals were calculated on the assumption that metals in the feedstock remain in the digested oolido. Data on initial concentrations of heavy metals in manure are shown in Table 3.4; these appear to be the only data available on heavy metals in manure. 9

Land and Water Use. About 3 acres, of land will be required for the facility, mostly for the algae lagoon. Water requirements are minimal.

\subsubsection{Capital Costs}

About $\$ 3$ million ( 1972 dollars) would be needed to build an anaerobic digestion system to recover energy from feedlot manure from 25,000 head of

Table 3.3. Residuals from Anaerobic Digestion of Manure from 25,000 Cattle

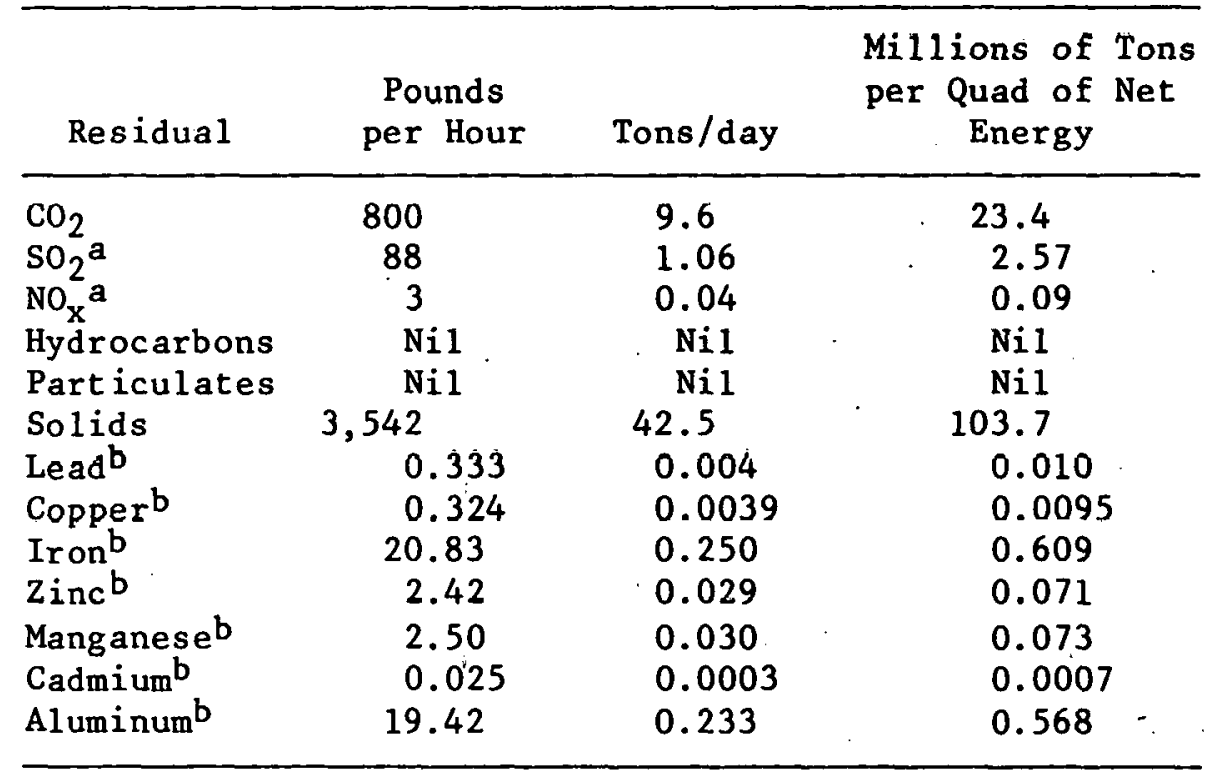

${ }^{a}$ Calculated.

${ }^{b}$ All metals in solids. 
Table 3.4. Metal Content of Manure in Various Stages of Digestion

\begin{tabular}{|c|c|c|c|c|c|c|c|}
\hline \multirow{2}{*}{$\begin{array}{c}\text { Digestion } \\
\text { St age }\end{array}$} & \multicolumn{7}{|c|}{ Content, ppm in Dry Solids } \\
\hline & $\mathrm{Pb}$ & $\mathrm{Cu}$ & $\mathrm{Fe}$ & $\mathrm{Zn}$ & Mn & $\mathrm{Cd}$ & Al \\
\hline First & 42 & 33 & 3300 & 320 & 380 & 1.5 & 3100 \\
\hline Second & 50 & $45^{\circ}$ & 3600 & 240 & 380 & 2.7 & 3000 \\
\hline Third & 52 & $80^{\prime}$ & 3000. & $300^{\circ}$ & 340 & 7.5 & 2700 \\
\hline Undigested & 48 & 22 & 1800 & 480 & 280 & 1.4 & 1900 \\
\hline Average $b$ & 48 & 45 & 2900 & 335 & 345 & 3 & 2700 \\
\hline
\end{tabular}

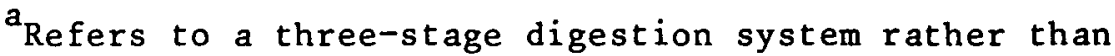
the two-stage system described in this study.

${ }^{b}$ These average values were used in this study to predict residual metal concentrations.

Source: Ref. 9.

cattle. Table 3.5 shows the breakdown of material, transport, and labor costs for the system.

\subsection{INCINERATION OF FEEDLOT MANURE '}

A search of the literature did not reveal any useful references to the incineration of manure for energy recovery. Most efforts in universities as well as by industry and government agencies are directed toward anaerobic digestion or pyrolysis for energy from animal residues. Incineration yields net energy as hot gases or steam, which could be used in a sludge treatment

Table 3.5. Construction Costs for an Anaerobic Manure Digestion Plant

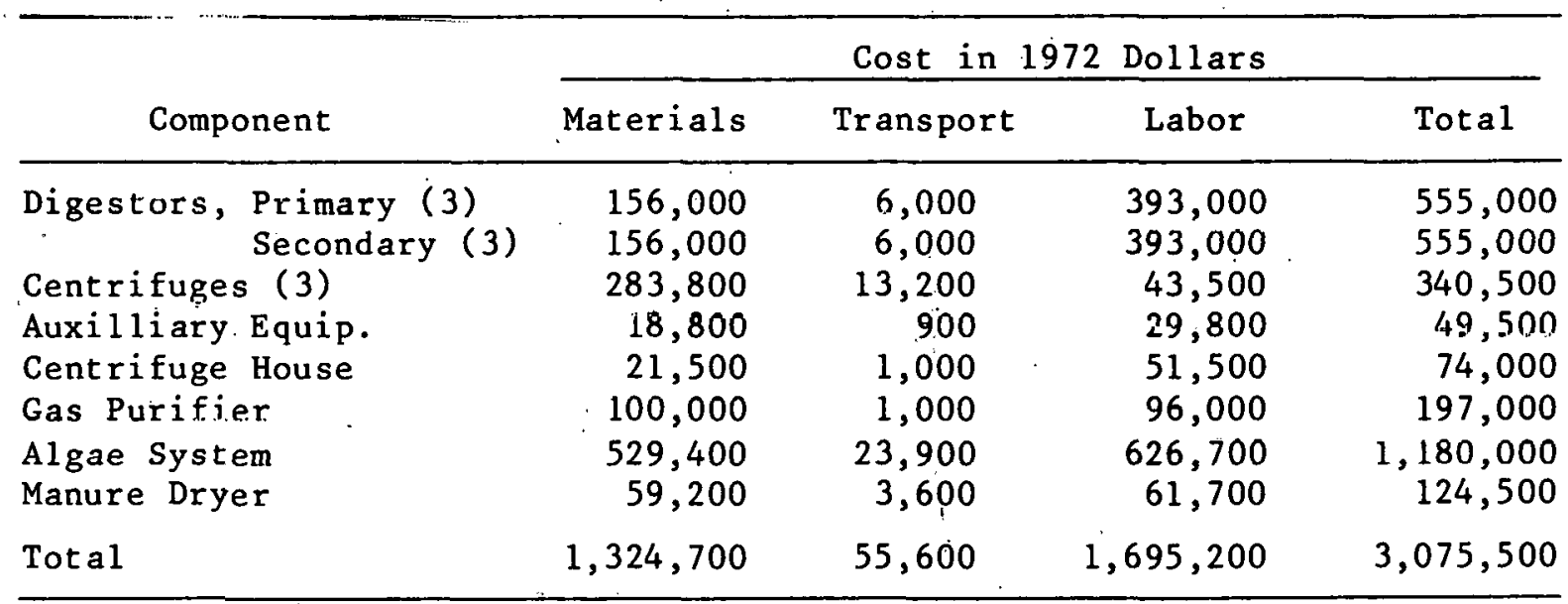




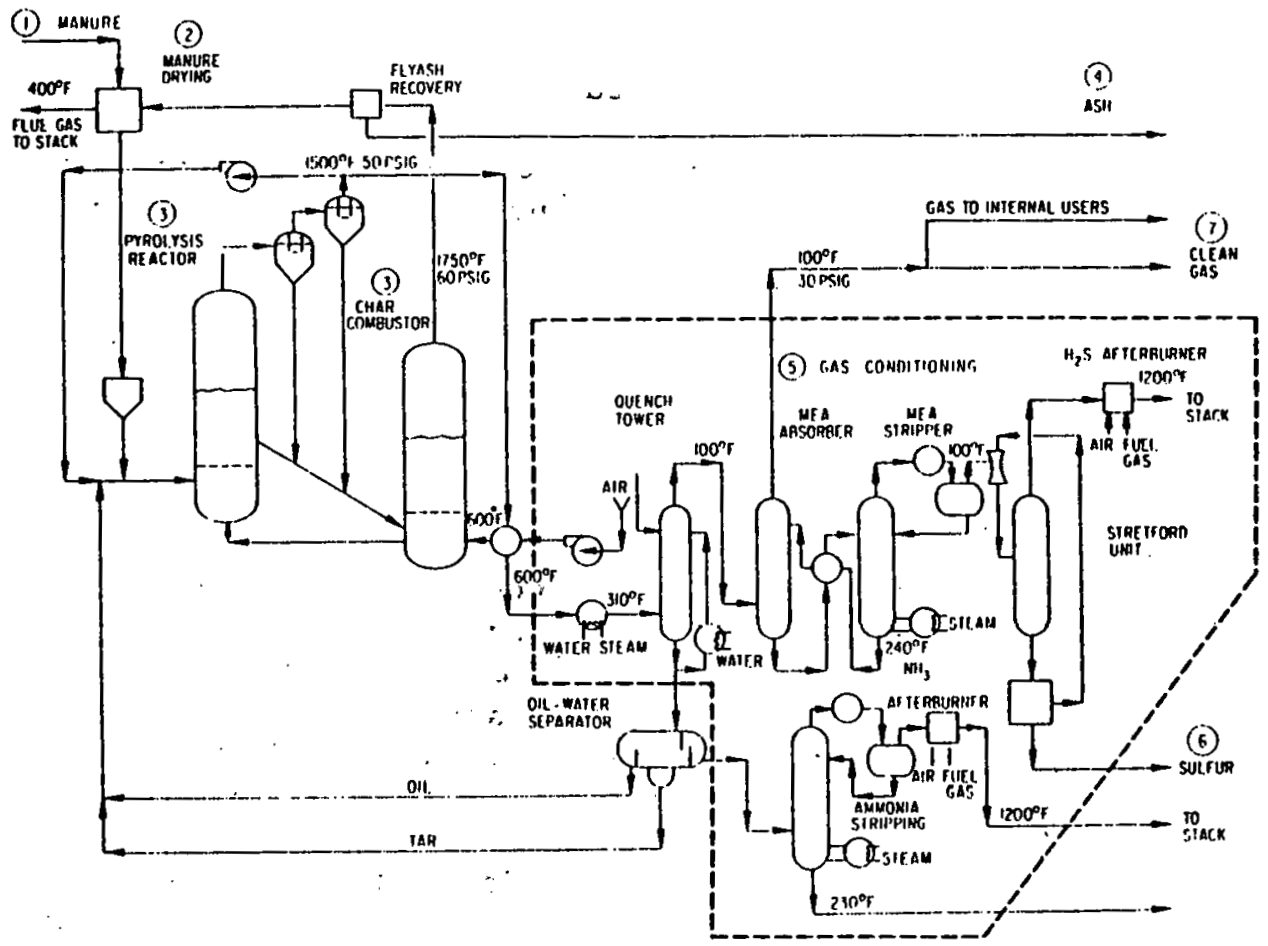

Fig. 3.2. Pyrolysis of Manure

\section{Stream Identification}

(1) Semicomposted Manure--41,666 $1 \mathrm{~b} / \mathrm{hr}$ of solids at $50 \mathrm{wt} \%$ solids, $37.8 \% \mathrm{C}$ in solids. Represents energy input of $356.2 \times 10^{6} \mathrm{Btu} / \mathrm{hr}$.

(2) Manure Drying--Gas from char combustor is cooled from $1750^{\circ} \mathrm{F}$ to $400^{\circ} \mathrm{F}$ as it dries the ground manure to $10 \mathrm{wt} \%$ water.

(3) Pyrolysis Reactor and Char Combustor--58\% of the $\mathrm{C}$ is pyrolyzed, yielding $13.7 \times 106 \mathrm{scf} /$ day of gas. Unreacted carbon goes on to the char combustor, where it burus lo provide heat for maintaining the endothermic pyrolysis reaction (via transfer of hot sand) and for manure drying.

(4) Ash--27.8\% of the manure solids becomes "ash, which has value as fertilizer.

(5) Gas Conditioning-- $\mathrm{CO}_{2}, \mathrm{H}_{2} \mathrm{~S}$, and $\mathrm{NH}_{3}$ are removed from the gas, which loses $29 \times 10^{6} \mathrm{Btu} / \mathrm{hr}$ in the process.

(6) Sulfur Recovesy--4.5 luns/day of sulfur are recovered from the Stretford-unit; the sulfur has value for. fertilizer production.

(7) Clean Gas- $-8.4 \times 10^{6} \mathrm{scf} /$ day of gas containing $8 \% \mathrm{CH}_{4}, 42 \% \mathrm{CO}$, and $48 \% \mathrm{H}_{2}$, with $387 \mathrm{Btu} / \mathrm{scf}$.

Energy Penalties: Gas conditioning, $29 \times 10^{6} \mathrm{Btu} / \mathrm{hr}$; sulfur recovery, $31 \times 10^{6}$ $\mathrm{Btu} / \mathrm{hr}$; incineration of waste gas, $94 \times 10^{6} \mathrm{Btu} / \mathrm{hr}$; gas cooling and stripping, $11.5 \times 10^{6} \mathrm{Btu} / \mathrm{hr}$; heat losses and reaction ëndothermy, $54.5 \times 10^{6} \mathrm{Btu} / \mathrm{hr}$.

Net Energy Recovered: $135.4 \times 10^{6} \mathrm{Btu} / \mathrm{hr}$ as low-Btu gas, representing about $38 \%$ of energy input as manure. 
plant but not to any great extent at a cattle feedlot. In addition, incineration leaves behind only ash, which does not have the considerable potential value of residues from anaerobic digestion of pyrolysis. For these reasons, incineration is not considered a useful method of energy recovery from manure and is not further addressed in this report.

\subsection{PYROLYSIS OF FEEDLOT MANURE}

\subsubsection{Process Characteristics}

The pyrolysis system assumed here would process manure from 145,000 cattle, or just under $1,000,000$ pounds of total solids per day. The plant contains a manure dryer, a pyrolysis reactor and char combustor, a process-gas cooling train, equipment for $\mathrm{CO}_{2}$ removal and sulfur recovery, condensate treatment apparatus, and waste gas incinerators. This system is similar to that conceived by Engler et al.;5 however, the $\mathrm{CO}_{2}$ removal system is more consistent with industrial. practice. Arrangement of these units is shown in Fig. 3.2. Energy characteristics of the model plant are given in Table 3.6.

Manure Drying. Semicomposted manure is brought to the plant containing $50 \%$ moisture. The manure must be ground to 60 mesh; ${ }^{5}$ a cage-mill flash-drying system can reduce the manure to this size and dry it at the same time by grinding it in the presence of hot gases from the char combustor. Drying is completed to $10 \%$ moisture content, as the, gases transport the ground manure to the pyrolysis reactor pneumatically. At the same time, the gas is cooled from $1,750^{\circ} \mathrm{F}$ at the combustor exit to about $400^{\circ} \mathrm{F}$. The wet gas is then sent to a flare stack where odors are removed by incineration before the flue gas is vented to the atmosphere.

Pyrolysis Reactor and Char Combustor. The manure is pyrolyzed in a fluidized-bed reactor. The pyrolysis reactor is a vertical, cylindrical pressure vessel with refractory-lined walls." A bed of sand stores heat and

Table 3.6. Energy Production Characteristics of Manure Pyrolysis in the Assumed Systema

\begin{tabular}{lc}
\hline Input, Btu/hr & $356 \times 10^{6}$ \\
Output, Btu/hr & $136 \times 10^{6}$ \\
Efficiency, $\%$ & 38 \\
Overall life, years & 20 \\
Energy produced nver 20 years, Btu & $2.38 \times 10^{13}$ \\
Number of plants to produce 1 & 42 \\
$\quad$ Quad over 20 years & $6.1 \times 10^{6}$ \\
Cattle to feed 42 plants & \\
\hline arocessing $8.7 \times 10^{6}$ pounds of raw manure $\left(10^{6}\right.$ \\
pounds of solids) per day from 145,000 cattle.
\end{tabular}


promotes the contact of the manure particles with hot gas, maintaining a uniform temperature of $1,500^{\circ} \mathrm{F}$ at $60 \mathrm{psig}$. The high heating rates that result have been shown to maximize gas yields. from the pyrolysis process. About $58 \%$ of the carbon in the manure is pyrolyzed, yielding $13.7 \mathrm{x}$ $10^{6} \mathrm{ft}^{3}$ per day of gas with the composition shown in Table 3.7 .5 This gas has a heating value of about 300 Btu/ft 3 After carbon dioxide, ammonia, and hydrogen sulfide are removed, the heating value increases to about $350^{\circ} \mathrm{Btu} / \mathrm{ft}^{3}$.

Unreacted carbon, along, with sand entrained in the pyrolysis gas, is removed by. high-efficiency cyclones. The dust-free gas is sent on to further processing; and the char and sand are pneumatically transported to the combustor.
Table 3.7. Pyrolysis Gas Compositiona

\begin{tabular}{lr}
\hline \multicolumn{1}{c}{ Component } & $\begin{array}{r}\% \text { by } \\
\text { Volumeb }\end{array}$ \\
\hline Carbon Monoxide & 33.3 \\
Hydrogen & 38.0 \\
Methane & 7.2 \\
Carbon Dioxide & 10.4 \\
Hydrogen Sulfide & 0.7 \\
Ammonia & 4.5 \\
Water & 5.8 \\
\hline anlume of gas produced is \\
13.68 x 10 ft $3 /$ day. \\
balues do not sum to $100 \%$ \\
because of rounding
\end{tabular}

Pyrolysis is an endothermic process, and heat is provided by combustion of unreacted carbon in the char combustor, which is also a fluidized-bed device. The heat required by the pyrolysis reactor is provided by circulating sand heated to about $1,750^{\circ} \mathrm{F}$ from the combustor to the pyrolysis reactor. Ash is blown from the bed, captured in a set of high-efficiency cyclones, quenched with cold water, and stored:

Process Gas Cooling. The pyrolysis gas is cooled in three steps. First, it is used to preheat the air fed to the char combustor to $500^{\circ} \mathrm{F}$. An air flow of $79,000 \mathrm{lb} / \mathrm{hr}$ takes up about $7.5 \times 10^{6} \mathrm{Btu}$ per hour, reducing the gas temperature to $600^{\circ} \mathrm{F}$. The gas then goes to the 50-psig steam generator wherc it is couled Lu $310^{\circ} \mathrm{F}$, giving tip approximately $2.3 \times 10^{6} \mathrm{Btu}$ per hour. This step produces about 2,600 pounds of steam per hour. Finally, the gas is cooled to $100^{\circ} \mathrm{F}$ by circulating cold water in the quench tower, which removes $1.7 \times 10^{6} \mathrm{Btu}$ per hour and purifies the gas of water-soluble contaminants (mainly ammonia). The cooled gas is treated to remove acid gases.

Acid Gas Removal. Acid gases (carbon dioxide and hydrogen sulfide) are absorbed in a packed column filled with monoethannlamine (MEA) in 10 wt\% solution in water. This contact lowers the hydrogen sulfide content of the pyrolysis gas to less than $10 \mathrm{ppm}$ and the carbon dioxide concentration t.n less thàn $50 \mathrm{ppm}$. The MEA circulation rate is approximately 425 gallons per minute.

Sulfur Recovery. The acid-gas-laden MEA stream is regenerated in the MEA stripper by reducing the pressure to about $56 \mathrm{psig}$ and heating the solvent to $240^{\circ} \mathrm{F}$. The heat input to the MEA stripper is about $31 \times 106$ Btu per hour. The regenerated MEA solution is cooled first by heat exchange with incoming MEA and then in a water cooler before recycling to the absorber column. 
The gas stream released in the MEA stripper is approximately $7 \%$ by volume hydrogen sulfide. The hydrogen sulfide is removed in a Stretford unit, a two-stage absorber consisting of a venturi chamber and a packed column containing anthraquinone disulfuric acid (ADA). The hydrogen sulfide is converted to a reduced $A D A-s u l f u r$ compound from which sulfur is recovered by blowing air through the solution; the sulfur precipitates and is recovered by filtration. About 4.5 tons of sulfur is recovered per day. The oxidizing air is sent to an incinerator.

Quench Condensate Treatment. A portion of the quench water used to cool the process gas in the final step is bled to the quench condensate treatment unit, which consists of an oil/water separator and an ammonia stripper. Although the pyrolysis reactor is expected to produced little oil, it is essential to the operation that oil not be allowed to accumulate. Heavy tars, char, and sand that might be in the quench water are also recovered and recirculated to the pyrolysis reactor.

Ammonia and hydrogen sulfide dissolved in the quench water are removed by boiling the water at about 5 psig. The recovered ammonia and hydrogen sulfide are sent to incineration, and purified water is rejected from the plant.

Waste Gas Incineration. All the waste gases from drying, sulfur recovery, and ammonia stripping are burned in separate incinerators. Each stream is mixed with sufficient fuel gas to allow an incineration temperature of $1,200^{\circ} \mathrm{F}$ when burned with $20 \%$ excess air. These incinerators represent a substantial energy penalty, equivalent to about 94 x 106 Btu per hour, or about $26 \%$ of the energy in the manure.

Materials. Material requirements for the construction of the pyrolysis system are given in Table 3.8 .

\subsubsection{Environmental Data}

Residuals and Effluents. Waste products from the model plant are summarized in Table 3.9. Distribution of metals between the water, stack

Table 3.8. Amounts of Materials Required for the Manure Pyrolysis Plant As sumed ${ }^{a}$

\begin{tabular}{|c|c|c|c|c|c|c|}
\hline \multirow[b]{2}{*}{ Component } & \multirow{2}{*}{$\begin{array}{c}\text { Steel, } \\
\text { Tons }\end{array}$} & \multirow{2}{*}{$\begin{array}{c}\text { Concrete, } \\
\text { Yards }\end{array}$} & \multirow{2}{*}{$\begin{array}{l}\text { Steel } \\
\text { Raschig } \\
\text { Rings, } \\
\text { Tons }\end{array}$} & \multirow{2}{*}{$\begin{array}{l}\text { Sand, } \\
\text { Tons }\end{array}$} & \multicolumn{2}{|c|}{ Brick, Tons } \\
\hline & & & & & Re fractory & Insul at ing \\
\hline Equi pment & 380 & 60 & 19 & 250 & 800 & 430 \\
\hline Building & 60 & 125 & - & - & - & - \\
\hline As sembly & 280 & 70 & - & - & - & - \\
\hline Total & 720 & 255 & 19 & 250 & 800 & 430 \\
\hline
\end{tabular}

a Processing manure from 145,000 cattile. 
emissions, and ash is given in Table 3.10. Stack emissions 1isted are associated with the waste gas incinerators; nitrogen oxides are calculated from data on low- and medium-Btu gases. Because most of the ammonia is removed in the quench tower, the emission of nitrogen oxides can be expected to be small.

Land and Water Use. One plant would need about 3 acres. Water usage is minimal; in fact, water will probably be produced from the plant in amounts that might be useful in an arid climate.

Table 3.9. Residuals from Pyrolysis of Manure from 145,000 Cattle

\begin{tabular}{lccc}
\hline Residuala & $\begin{array}{c}\text { Pounds } \\
\text { Per Hour }\end{array}$ & Tons/Day & $\begin{array}{c}\text { Millions of Tons } \\
\text { per Quad of Net } \\
\text { Energy }\end{array}$ \\
\hline $\mathrm{CO}_{2}$ & 7650.0 & 91.8 & 28.1 \\
$\mathrm{SO}_{2}$ & 0.75 & 0.009 & 0.00275 \\
$\mathrm{NO}_{\mathrm{x}}$ & 69.6 & 0.835 & 0.256 \\
Hydrocarbons & $\mathrm{Ni1}$ & $\mathrm{Ni1}$ & $\mathrm{Ni1}$ \\
Particulates & $\mathrm{Ni1}$ & $\mathrm{Ni1}$ & $\mathrm{Nil}$ \\
Lead & 2.00 & 0.024 & 0.007 \\
Copper & 0.92 & 0.011 & 0.007 \\
Iron & 75.00 & 0.900 & 0.444 \\
Zinc & 20.00 & 0.240 & 0.051 \\
Manganese & 11.67 & 0.140 & 0.053 \\
Cadmium & 0.06 & 0.001 & 0.005 \\
Aluminum & 79.17 & 0.950 & 0.413 \\
\hline
\end{tabular}

${ }^{\mathrm{a}}$ Calculated

Table 3.10. Distribution of Metals in Manure-Pyrolysis Wastes, Per Quad of Energy Produced

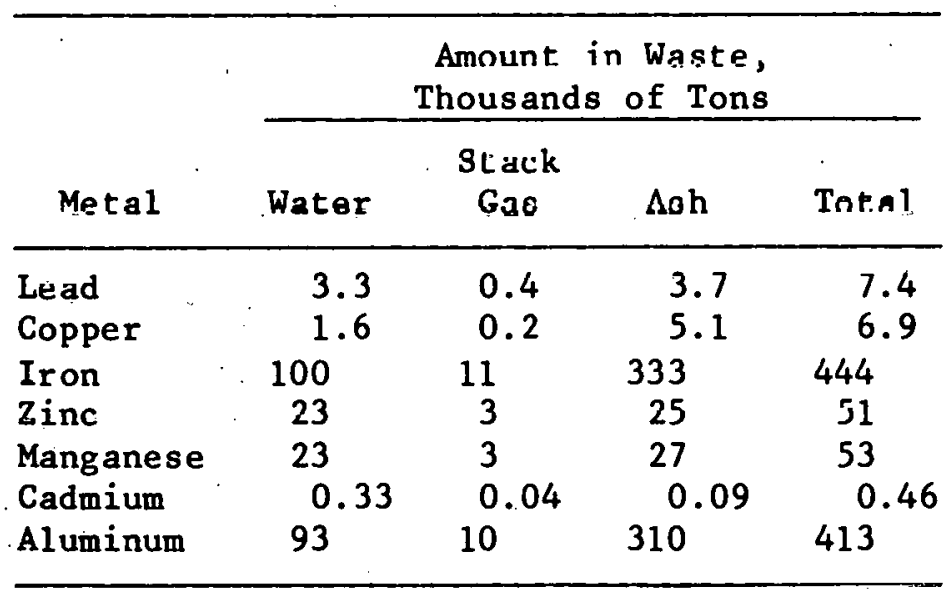




\subsubsection{Capital Costs}

This is a capital-intensive system. Therefore a large installation is required to reduce the amortization payment part of the gas cost. 5 Cost data are summarized in Table 3.11 .

$$
\text { uis }
$$

Table 3.11. Construction Costs f̂̀̂̀r a Fluidized-Bed Manure Pyrolysis Plant

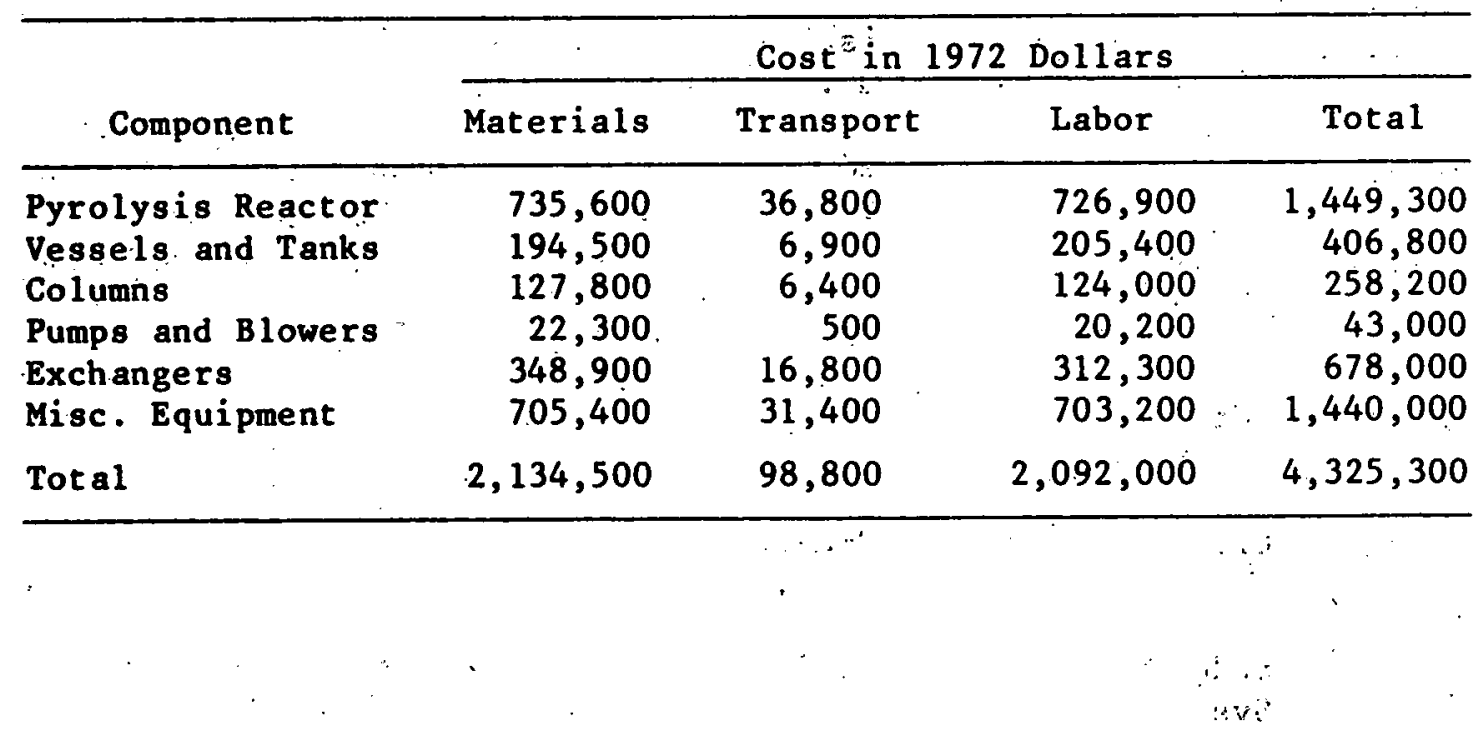


THIS PAGE

\section{WAS INTENTIONALLY LEFT BLANK}




\section{DISCUSSION}

The energy recovery systems described in this report would probably be sited near large sources of concentrated sludge or feedlot manure. In 1973, nine states -- Texas, Nebraska, Iowa, Kansas, Colorado, California, Illinois, Arizona, and Minnesoata -- accounted for over $80 \%$ of the total number of cattle in U.S. feedlots. 18 Several environmental impacts are associated with feedlots, especially those that collect the deposited manure only intermittently. Runoff from feedlot waste can severely lower dissolved oxygen levels in streams, producing biological oxygen demand and ammonia concentrations reaching 80 and $12 \mathrm{mg} / \mathrm{L}$, respectively. 3 Feedlots also contribute ammonia, amines, and odorous sulfur compounds to the atmosphere. ${ }^{3}$

Anaerobic digestion of manure does not degrade the fertilizer and soil conditioner value of the digested residue. The residue can, in fact, be dried and recycled as a proteinaceous livestock feed additive. 19

Municipal sludge can be found in any metropolitan area. Medium and large urban areas have sewage collection systems and treatment facilities to which any of the conversion systems described could be added with little difficulty. Municipal sludge is generally considered a waste disposal problem, especially as competition for land increases and sanitary landfill sites become less available.

There are, however, major environmental constraints associated with these conversion technologies, in their potential for releasing atmospheric pollutants and heavy metals. Metropolitan areas produce large quantities of sludge, but they are also often categorized as nonattainment areas with regard to air pollution. Under EPA's emission offset policy, construction and operation of any new combustion facility in a nonattainment area will require more than an equivalent reduction in emissions from other sources in the area. An investigation of potential siting patterns and pollution conflicts is needed before energy recovery systems using municipal sludge can be considered as feasible energy supply sources.

Finally, fluidized-bed incineration deserves evaluation. Many municipalities are using such systems for sludge reduction, and it would be remiss not to analyze this process. The use of municipal refuse as a fuel supplement

for sludge incineration should also be investigated. This scheme is being increasingly considered by municipal authorities concerned with waste disposal. 


\section{THIS PAGE}

WAS INTENTIONALLY

LEFT BLANK 
RE FERENCE S

1. Burford, J.L., and F.T. Varani, Energy Potential Through Bio-Conversion of Agricultural Wastes, final report to Four Corners Regional Commission, FCRCGrant No. 651-366-075, Bio-Gas of Colorado (1976).

2. Municipal Sludge Management: Environmental Factors, EPA 430/9/77/004, U.S. Environmental Protection Agency (Oct. 1977).

3. Loehr, R.C., Pollution Control for Agriculture, Academic Press, New York (1977).

4. Miner, J.R., and R.S. Smith (eds.), Livestock Waste Management with Pollution Control, North Central Regional Research Pub. 222, MWPS-19, Midwest Plan Service, Iowa State University, Ames (1975).

5. Engler, C.R., W.P. Walawender, and L.T. Fan, Synthesis Gas from Feedlot Manure: Conceptual Design Study and Economic Analysis, Environ. Sci. Tech., Volume 9, No. 13 (Dec, 1975).

6. Process Design Manual for Sludge Treatment and Disposal, EPA 625/1-74-006, U.S. Envi ronmental Protection Agency (Oct. 1974).

7. Sanghi, A.K., and D. Day, A Cost-Benefit Analysis of Biogas Production in Rural India: Some Policy Issues, Washington University, St. Louis, Mo. (undated).

8. Mitre Corp., Energy Conservation Waste Utilization Research and Development Plan, Technical Report MTR-3063, Contract No. E-(49-1) - 3764, Energy Research and Development Administration.

9. A Complete Disposal-Recycle Scheme for Agricultural Solid Wastes, Tennessee State University, EPA/600/2-77-089.

10. Personal communication from personnel of Bio Gas of Colorado Inc., 5620 Kendall Court, Arvda, Colo. 80002.

11. Manual of Practice No. 8, Water Pollution Control Federation (1977).

12. Commers, L.E., Chemical Composition of Sewage Sludges and Analysis of Their Potential Use as Fertilisers, JEQ6:225-239 (1977).

13. Telephone conversation with personnel of BSP Division, Envirotech Corp., 1 Davis Drive, Belmont, Calif. 94002.

14. Telephone conversation with personnel of Shriver Division, Envirotech Corp., 850 Hamilton Street, Harrison, N.J. 07029. 
15. Telephone conversation with personnel of Greenbay, Wisc., Metropolitan Sanitary District. $43 i$

16. Bracken, Siegar, Coe, and Allen, Energy from Solid Waste for Wastewater Treatment - Demonstration Project, 50th Annual Conference Water Pollutión Control Federation (Oct. 1977)

17. Telephone conversation with personnel of Sharples Centrifuge Division, Pennwalt Corp., Oakbrook, I1:

18. Inman, R.E., An Evaluation of the Use of Agricultural Residues as an Energy Feedstock, NSF/RANN/SE/GI-4385971 PR/72/4 (Feb. 1975).

19. Hanson, J,A, et al. SNG fröm Biomass; An Overviens and Recommentations for Further $R D \& D$, prepared for the Gas Research Institute by Jet Propulision: Laboratory, California Institute of Technology, Pasadena (Jan. 1978).

20. EPA Construction Grants Program, An Overview of the Sludge Management. $\therefore$ Situation, EPA 430/9-76-009. 
BIBLIOGRAPHY

Huffman, W.J., J.E. Halligan, R.L. Peterson, and E. DelaGarza, Ammonia Synthesis Gas and Petrochemicals from Cattle Feedlot: Manure, Symposium on Clean Fuels from Biomass and Wastes, Orlando, Fla. (Jan. 25-28, 1977).

Johnson, W.H., Anaerobic Digestion Design Advances Increase Energy Production, Envirotech, Water Pollution Control Federation Convention (Sept. 1976).

Manual of Practice No. 11, Water Pollution:Control Federation (1977).

O'Dette, R., Pretreatment: A Dilemma for Industry, Tennessee Division Water Quality Control, 6th Annual Industrial Pollution Conference, WWEMA (Apr. 1978).

Sebastian, F., et al., Solid Waste Disposal, Deskbook Issue, Chemical Engineering (Oct. 1968).

Solar Program Assessment: Environmental Factors: Fuels from Biomass, ERDA 77/47/7; UC-11, 59, 62, 63A (Mar. 1977). 